\title{
EXPERIMENTAL AND NUMERICAL STUDY OF THE EFFECT OF HEATED OBSTRUCTION WITHIN A SPACE (WELDING WORKSHOP) ON THREE DIMENSIONAL AIR FLOW CHARACTERISTIC
}

\author{
Hala Jasim Maki, \\ University of Basra, Basra, Iraq. \\ E-mail: starrom80@gmail.com \\ Dr. Emad Abdala Khazaal, \\ University of Basra, Basra, Iraq. \\ E-mail: Emad.ab74@gmail.com \\ Ass. Prof. Ali Abd-Almonaaem \\ University of Basra, Basra, Iraq. \\ E-mail: archengineer1@gmail.com
}

Received on 31 October 2017 Accepted on 8 April 2018 Published on 14 May 2018

DOI: $10.30772 /$ qjes.v11i1.523

\begin{abstract}
This study investigates experimentally and numerically the environmental conditions prevailing in a large mechanically ventilated welding workshop which lies in the Basra Oil Training Institute in Iraq. The numerical part was accomplished with the aid of the computational fluid dynamics by ANSYS 15 program. This software program was compared against the results of a resemblance research work [1], which shows a good agreement. Numerical results are compared with experimental data collected during different ventilation and occupational conditions of empty and full workshop daily work, and there is a good agreement between experimental data and numerical results. The experimental part was done by using suitable calibrated devices to measure the air velocity, temperature, relative humidity and concentration of $\mathrm{CO}, \mathrm{CO}_{2}$ gases in the different locations of the indoor environment of welding workshop. The results of this study demonstrate that the occupants of the existed welding workshop suffer from healthy problems because of the harmful gases, and the inefficient ventilation system used.
\end{abstract}


Keywords: $\mathrm{CO}_{2}$ concentration, welding workshop, Obstruction, Mechanically Ventilated.

\section{INTRODUCTION}

Appropriate ventilation and supply of natural air play a major part in the control of the indoor air quality and thermal comfort given that metabolism is intense due to the overcrowding of people. The Computational fluid dynamics (CFD) codes have become an important tool in the research field of air quality, in both the indoor and outdoor environments. They are currently applied for investigations of indoor airflow fields for building design and optimum ventilation purposes and for pollutants dispersion in working areas for health and safety reasons. But, limited studies join theoretical and experimental methods to study air quality in an industrial environment, where a certain level of harmful gases and contaminants might be emitted during industrial processes. ( Khanooba, M, R, 2015)

Abduljabbar Muttair, 2010, detailed a numerical investigation of three-dimensional turbulent buoyant recirculating flow inside a room with heated obstruction. The energy usage coefficient increase with decrease in size of obstruction. Concentration of $\mathrm{CO}_{2}$ is maximum above the obstruction and reduce with reduction in the size of the obstruction.

Rahman, et.al, 2014, conducted a simulation works which included the velocity of air and particle dispersion in mechanically ventilated laboratory space. In this study the researchers were using the device of Anemometer to measure the air velocity.

Welding can be defined as a process that joins materials, generally metal, by fusion. This is done by melting the components and adding a filler material to form a puddle of molten material which after that cools to become a strong joint. ( G. Buonanno ,n, L.Morawska, Stabile, 2011)

Although the importance of the welding process, but on the other side welding is an actually hazardous activity that includes a unique combination of both health and safety risks to more than 500,000 workers in a wide variety of industries. ( Azian Banti Harir,2015)

Depending on the welding process used, welders can be exposed to metals in fume such as manganese, iron, aluminum, lead, nickel, copper, chromium, arsenic and zinc. Also, arc welders can be exposed to toxic gases, such as ozone, carbon monoxide, nitrogen oxide, and nitrogen dioxide. (Jeffrey $\mathbf{R}$. Walls, 2012)

This paper deals with a numerical study done by (Fluent) program within ANSYS 15, of the thermal environment of a welding workshop located in the Basra Oil Training Institute. The welding machines are considered to be the heated obstructions. The numerical results are also supported by some experimental measurements accomplished in the above mentioned workshop, the numerical and experimental 


\section{AL-QADISIYAH JOURNAL FOR ENGINEERING SCIENCES}

Vol. 11, No. 1

ISSN: $1998-4456$

investigations of the under study were done under different cases of occupation conditions in the workshop and the problems of air conditioning unhealthy environment, and air distribution or accumulation are also tried to be solved. The comfortable and healthy environment of the welding workshop assist the technical staff to provide good student training, and encourage the students to do their jobs more efficiently.

\section{METHODOLOGY}

\subsection{EXPERIMENTAL PART}

The welding workshop under study is in close vicinity of heavy-traffic roads. The area of the indoor space is $204 \mathrm{~m}^{2}$, while its height is $9 \mathrm{~m}$. The capacity of the welding work shop is (25-35) students and the number of the welding machines is (15). There are three windows at the north wall which normally closed and no heating-ventilating-air conditioning (HVAC) system is exits, except a forced ventilation system consisting of 10 exhaust fans with of capacity (41.6) $\mathrm{m}^{3} / \mathrm{min}$ for each one and are fitted in the three sides of the wall (i.e. north, east and south), while the fresh air is introduced through the inlet door in the (south) side of the work shop. The inlet door is always kept open permitting the air changing per hour of the work shop for healthy purposes. Measurements were taken at different locations in the workshop for both cases, the empty workshop case and full of students and trainers case. The main instrument used was (Data logging / Printing Anemometer + Psychomotor) [7] , as shown in Figure(1). This device simultaneously measures and displays air velocity, temperature, humidity, wet bulb temperature, and flow rate (CFM / CMM). Surface temperatures of indoor materials were measured with an infrared thermometer, as shown in Figure(2). The concentration of the gases of the $\mathrm{CO}$ and $\mathrm{CO}_{2}$ were measured with TETRA GAS DETECTOR and Ventilator Intelligent Controller (KF-900F) respectively, as shown in Figures(3) and (4).

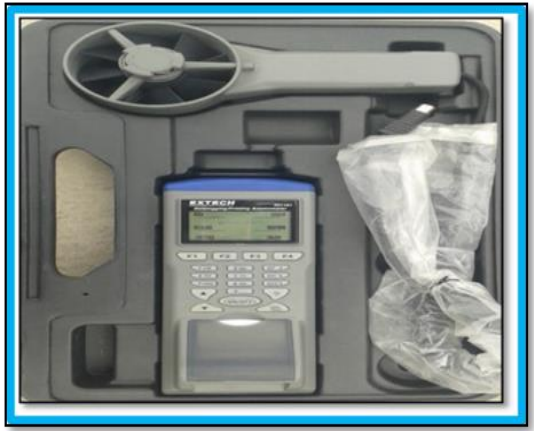

Figure 1:(Data logging / Printing Anemometer + Psychomotor)

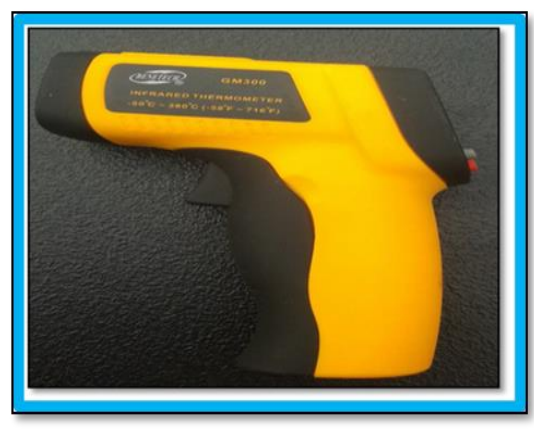

Figure 2: Infrared thermometers 


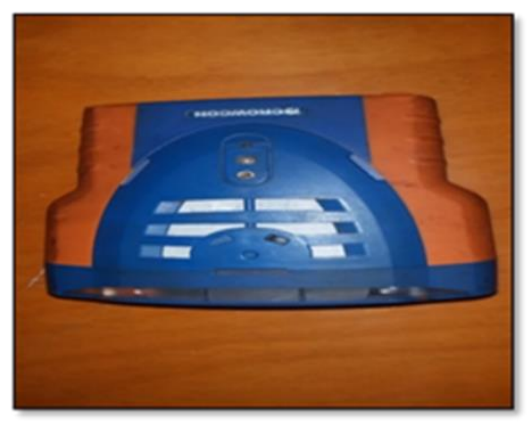

Figure 3 :TETRA GAS DETECTOR

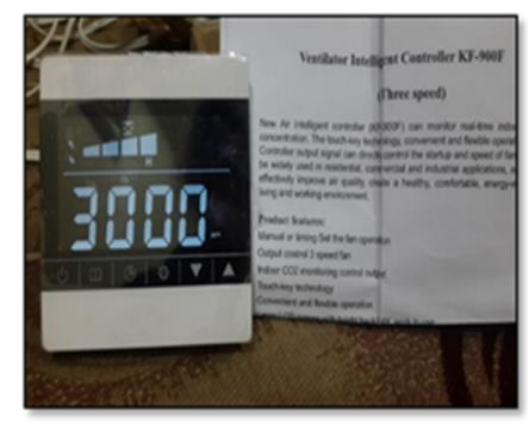

Figure 4 :Ventilator Intelligent Controller (KF-900F)

\subsection{Theoretical Model}

The ANSYS 15 (CFD) code [8] solves the time-averaged conservation equations of mass, momentum, and chemical species in three-dimensional flows:

Equation (1) is the unsteady, three-dimensional mass conservation equation at a point in a compressible fluid.

$$
\frac{\partial \rho}{\partial t}+\frac{\partial}{\partial x_{j}}\left(\rho U_{j}\right)=0
$$

Equation (2) is represented the conservation of momentum (Navier-Stokes equations)

$$
\frac{\partial \rho U_{i}}{\partial t}+\frac{\partial}{\partial x_{j}}\left(\rho U_{i} U_{j}\right)=-\frac{\partial p}{\partial x_{i}}+\frac{\partial}{\partial x_{j}}\left(\tau_{i j}-\rho \bar{u}_{i} \bar{u}_{j}\right)+S_{M}
$$

where $\tau$ : Molecular stress tensor

$\mathrm{S}_{\mathrm{M}}$ :Source Term

P: pressure

The turbulence kinetic energy, $\mathrm{k}$, and its rate of dissipation, $\varepsilon$, are obtained from the following transport equations:

$$
\begin{aligned}
& \frac{\partial}{\partial t}(\rho k)+\frac{\partial}{\partial x_{i}}\left(\rho k u_{i}\right)=\frac{\partial}{\partial x_{j}}\left[\left(\mu+\frac{\mu_{t}}{\sigma_{k}}\right) \frac{\partial k}{\partial x_{j}}\right]+G_{K}+G_{b}-\rho \varepsilon-Y_{M}+S_{k} \quad \text { (3) [ 9] } \\
& \frac{\partial}{\partial t}\left(\rho \varepsilon G_{b}\right)+\frac{\partial}{\partial x_{i}}\left(\rho \varepsilon u_{i}\right)=\frac{\partial}{\partial x_{j}}\left[\left(\mu+\frac{\mu_{t}}{\sigma_{\varepsilon}}\right) \frac{\partial \varepsilon}{\partial x_{j}}\right]+C_{1 \varepsilon} \frac{\varepsilon}{k}\left(G_{K}+C_{3 \varepsilon}\right)-C_{2 \varepsilon} \rho
\end{aligned}
$$


$G_{K}$ represents the generation of turbulence kinetic energy due to the mean velocity gradients, calculated as described :

$$
G_{K}=-\rho \bar{u}_{i}^{\prime} \vec{u}_{j}^{\prime} \frac{\partial u_{j}}{\partial x_{i}} \quad \text { (5) [ 9] }
$$

$G_{b}$ is the generation of turbulence kinetic energy due to buoyancy, calculated as described in

$$
G_{b}=\beta g_{i} \frac{\mu_{t}}{\operatorname{Pr}_{t}} \frac{\partial T}{\partial x_{i}} \quad \text { (6) [9] }
$$

where $\mathrm{Pr}_{t}$ is the turbulent Prandtl number for energy and ${ }^{g_{i}}$ is the component of the gravitational vector in the ith direction. For the standard and realizable k- $\varepsilon$ models, the default value of $\operatorname{Pr}_{t}$ is 0.85 . The coefficient of thermal expansion, $\beta$, is defined as

$$
\beta=-\frac{1}{\rho}\left(\frac{\partial \rho}{\partial T}\right)_{p} \quad(7)[9]
$$

$Y_{M}$ represents the contribution of the fluctuating dilatation in compressible turbulence to the overall dissipation rate which is normally neglected in the modeling of incompressible flows and it can neglected in this study.

Where $C_{1 \varepsilon}, C_{2 \varepsilon}, C_{3 \varepsilon}$ are constants. $\sigma_{k}$ and $\sigma_{\varepsilon}$ are the turbulent Prandtl numbers for $\mathrm{k}$ and $\varepsilon$, respectively, $S_{k}$ and $S_{\varepsilon}$ are user-defined source terms.

In this study, conservation equations for chemical species are solved, so ANSYS Fluent predicts the local mass fraction of each species, $Y_{i}$, through the solution of a convection-diffusion equation for the $i^{\text {th }}$ species. This conservation equation takes the following general form:

$$
\frac{\partial}{\partial t}\left(\rho Y_{i}\right)+\nabla \cdot\left(\stackrel{\mathrm{r}}{\rho Y_{i}}\right)=-\stackrel{\mathrm{r}}{\mathrm{J}}_{i}+R_{i}+S_{i} \quad \text { (8) [ 9] }
$$

where $R_{i}:$ The net rate of production of species $i$ by chemical reaction

and $S_{i}$ : The rate of creation by addition from the dispersed phase plus any user-defined sources 
$\mathbf{J}_{i}$ : The diffusion flux of species $i$ which arises due to gradients of concentration and temperature.

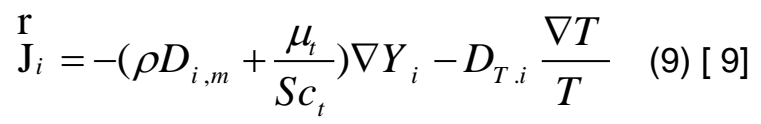

$S c_{t}:$ The turbulent Schmidt number

$\mu_{t}:$ The turbulent viscosity

$D_{T, i}:$ Turbulent diffusivity

The Total Energy Equation can be represented as :

$$
\frac{\partial}{\partial t}\left(\rho h_{t o t .}\right)-\frac{\partial p}{\partial t}+\nabla \cdot\left(\rho U h_{t o t .}\right)=\nabla \cdot(\lambda \nabla T)+\nabla \cdot(U . \tau)+U S_{M}+S_{E} \quad \text { (10) [ 9] }
$$

Where $h_{\text {tot }}$, is the total enthalpy, related to the static enthalpy $\mathrm{h}(\mathrm{T}, \mathrm{P})$ by:

$$
h_{\text {tot. }}=h+\frac{1}{2} U^{2}
$$

The term $\nabla .(U . \tau)$ represents the work due to viscous stresses and is called the viscous work term. This models the internal heating by viscosity in the fluid, and is negligible in most flows.

The term $U S_{M}$ represents the work due to external momentum sources and is currently neglected.

$S_{E}$ : energy source

\section{$\lambda$ : thermal conductivity}

As seen in Table (2) the dimensions of the objects are real, the geometry is as detailed as possible according to the plans of the building. The domain size is $(17 \mathrm{~m} \times 12 \mathrm{~m} \times 9 \mathrm{~m} \mathrm{~L}, \mathrm{~W}, \mathrm{H})$, and it includes 15 cabins, each cabin contains welding machine, table and a student working on the machine. These cabins are positioned at (west, east and north sides of the workshop). The total number of students in the work shop are 35. Only 15 students are busy in the welding process, while the others are waiting for their role, and in the 


\section{AL-QADISIYAH JOURNAL FOR ENGINEERING SCIENCES}

Vol. 11, No. 1

ISSN: $1998-4456$

same time preparing the working pieces. There are 3 trainers in the workshop always available. The boundary conditions for the cases which is studied (empty and full case) is listed in the Figuers1. and 2. The convergence criterion was set such that the respective sum of the absolute residuals must be less than $10^{-4}$.

\subsection{VALIDATION OF PRESENT CFD PROGRAM}

In the present study, ANSYS 15 program is validated against a previous research done by Abduljabbar Muttair [1]. For this purpose, the above program is used to design a room of dimensions ( $\mathrm{L}=5.4$ $\times \mathrm{H}=2.5 \times \mathrm{W}=3.6 \mathrm{~m}$ ), similar to that considered in the previous compared with research work [1]. This room includes a heated obstruction of different size (small, medium and large). The thermal performance of this room comprising the distribution of temperature, velocity, and $\mathrm{CO}_{2}$ concentration inside the designed room. All the results in this verification case were in good agreement with the previous once. As seen in the Table 1. and Figure (5), it has been taken the air temperature for twenty points in the domain of room and compered between these results and the previous results.

Table.1 Values of air temperatures at selected points of the domain for the pervious study and validation case.

\begin{tabular}{|c|c|c|c|c|c|}
\hline \multirow{2}{*}{ Point } & \multicolumn{3}{|c|}{ Location } & \multirow{2}{*}{$\begin{array}{cc}\text { Results of } & \text { pervious } \\
& \text { study } \\
& \mathrm{T}_{\mathrm{NU}} . \\
\mathrm{K} & \end{array}$} & \multirow{2}{*}{$\begin{array}{c}\text { Results of } \\
\text { validation case } \\
\mathrm{T}_{\mathrm{NU}} . \\
\mathrm{K}\end{array}$} \\
\hline & $x$ & Y & $Z$ & & \\
\hline 1 & 0.4 & 0.6 & 1.8 & 296.29 & 295.87 \\
\hline 2 & 0.4 & 0.6 & 1.8 & 296.35 & 296.98 \\
\hline 3 & 0.4 & 2.4 & 1.8 & 296.06 & 294.23 \\
\hline 4 & 0.5 & 2.4 & 1.8 & 296.06 & 295.12 \\
\hline 5 & 0.6 & 2.1 & 1.8 & 294.72 & 293.59 \\
\hline 6 & 0.6 & 2.4 & 1.8 & 295.91 & 293.56 \\
\hline 7 & 1.5 & 0.3 & 1.8 & 296.57 & 294.21 \\
\hline 8 & 2 & 0.4 & 1.8 & 296.85 & 293.98 \\
\hline 9 & 2.2 & 1.1 & 1.8 & 297.34 & 295.34 \\
\hline 10 & 2.3 & 0.7 & 1.8 & 297.61 & 296.13 \\
\hline 11 & 2.4 & 0.5 & 1.8 & 298.33 & 295.99 \\
\hline 12 & 2.5 & 1.2 & 1.8 & 299.05 & 296.55 \\
\hline 13 & 3 & 1.5 & 1.8 & 296.85 & 293.48 \\
\hline 14 & 3.1 & 1.2 & 1.8 & 296.57 & 296.21 \\
\hline 15 & 4.7 & 0.7 & 1.8 & 296.06 & 295.56 \\
\hline
\end{tabular}




\begin{tabular}{|l|l|l|l|l|l|}
\hline 16 & 4.6 & 2 & 1.8 & 295.53 & 293.35 \\
\hline 17 & 4.9 & 1.5 & 1.8 & 295.61 & 293.56 \\
\hline 18 & 4.8 & 2.4 & 1.8 & 295.91 & 294.26 \\
\hline 19 & 4.5 & 2.5 & 1.8 & 296.06 & 293.26 \\
\hline 20 & 4.9 & 2.1 & 1.8 & 295.59 & 294.78 \\
\hline
\end{tabular}

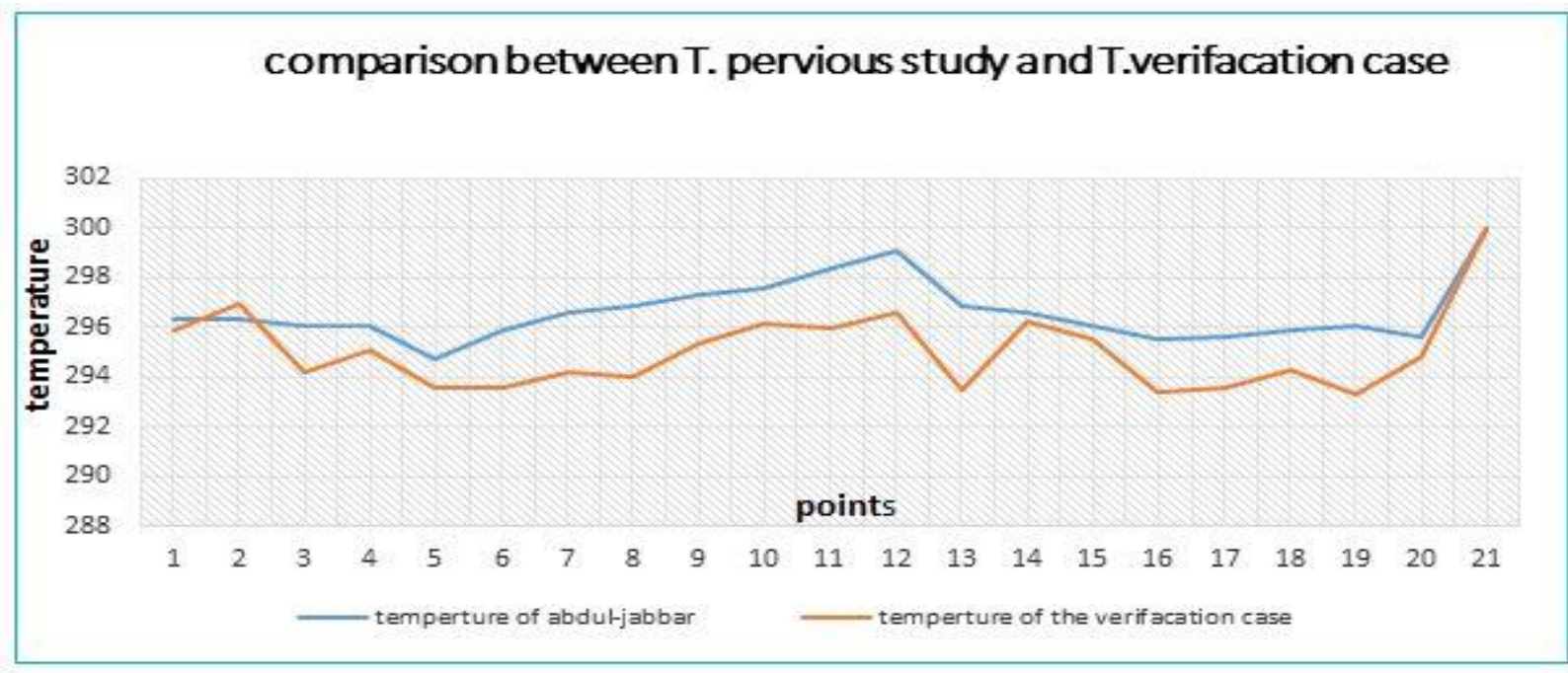

Figure 5: Comparison of numerical values of temperature of the domain points between T.pervious study and T.verifacation case [1].

\section{RESULTS AND DISCUSSION}

\subsection{VERIFICATION CASE}

This case corresponds to the validation process, indicated to latterly, where the program used in this paper is checked against the results of the research work of Abduljabbar [1].

The present computations are performed under steady state conditions by solving equations of the conservation of mass, momentum, energy and concentrations. Preprocessing requires the construction of geometry and generation of the mesh on the surfaces or volumes. This was done with the software gambit, linked to Fluent for the pervious study, while in the present verification case this is done by using design modeler through ANSYS program. Before starting a simulation, the physical models have to be tackled. The SIMPLE algorithm is employed as the pressure-velocity coupling method [1] . The mesh which employed for pervious study and verification study, the computed distributions of velocity streamlines and temperature contours in the room under study are illustrated in Figure (6) for large size of obstruction. It is observed that 


\section{AL-QADISIYAH JOURNAL FOR ENGINEERING SCIENCES}

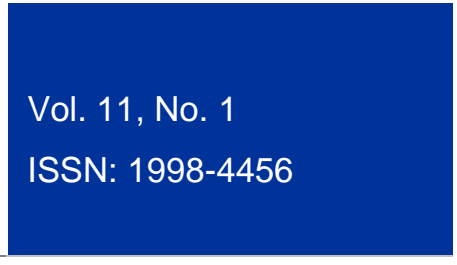

there is a good matching between two results when compared between these results, as shown in the Figure (1). This lends legitimacy to this program which used in the current study.

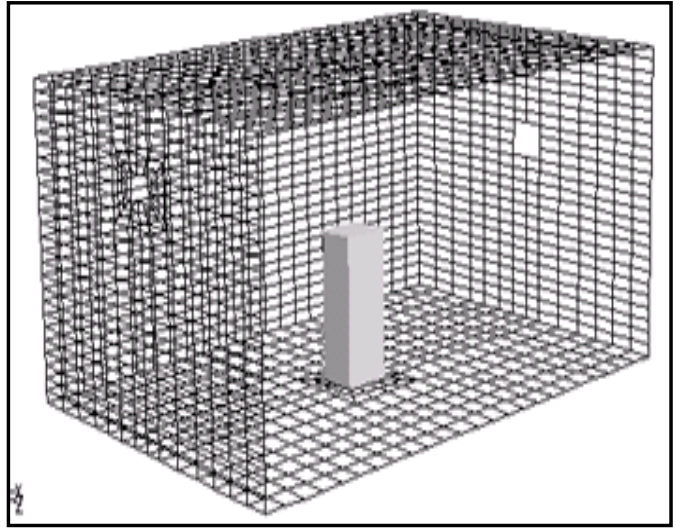

(a)

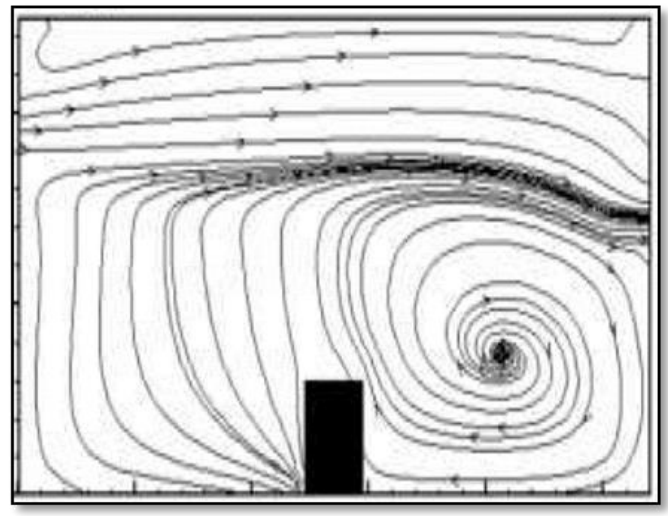

(c)

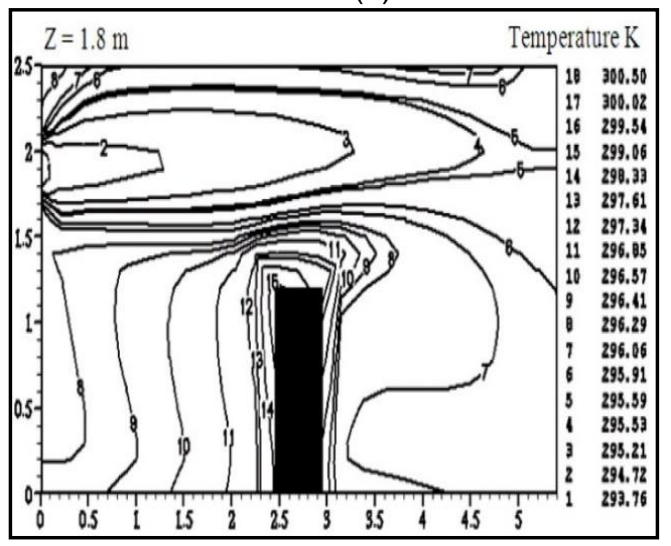

(e)

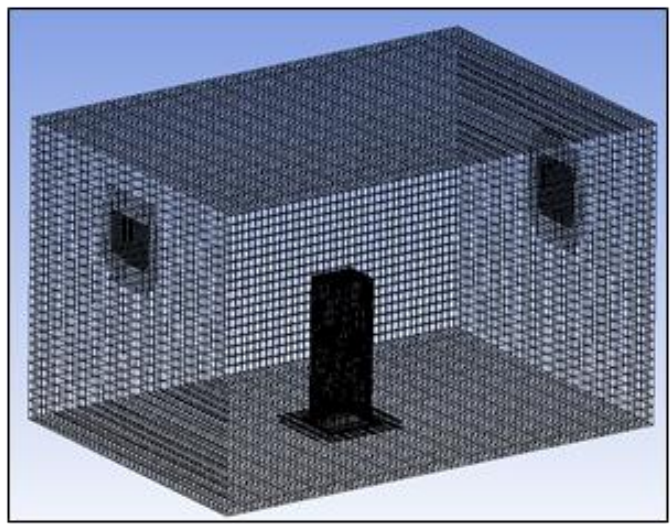

(b)

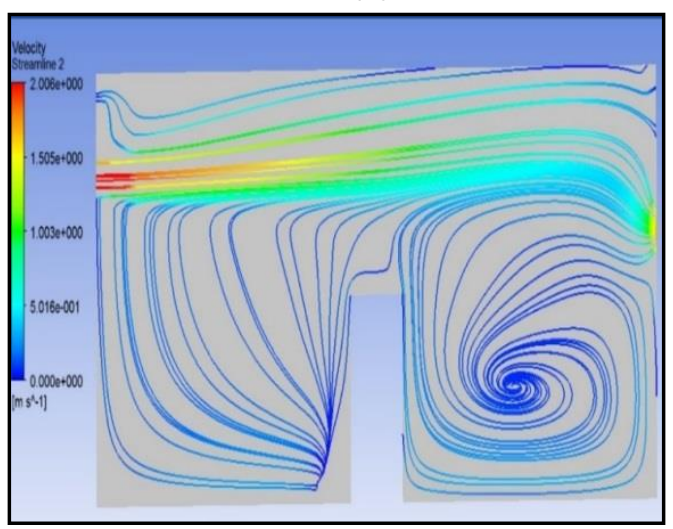

(d)

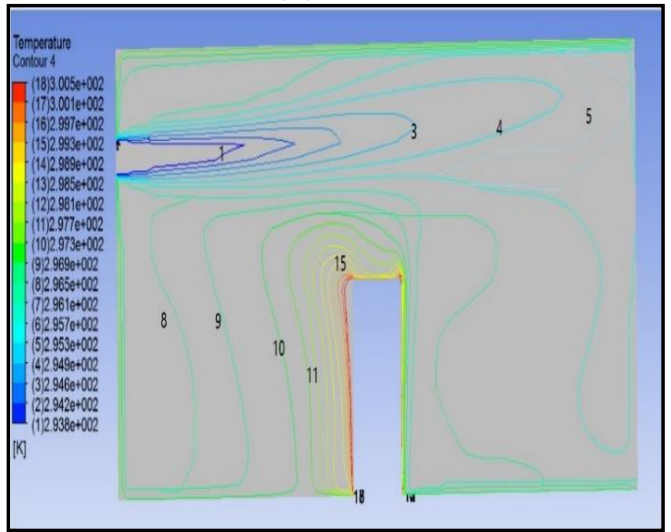

(f)

Figure 6 : Comparison between pervious study and verification case (a) Mesh employed for the previous study, (b) Mesh employed for the verification case, (c) Velocity streamline for pervious study, (d) Velocity streamline for verification case, (e) Temperature contour for pervious study, (f) Temperature contour for verification study 
AL-QADISIYAH JOURNAL FOR ENGINEERING SCIENCES
Vol. 11 , No. 1

ISSN: $1998-4456$

Table 2. Dimension and position of the objects in the welding workshop

\begin{tabular}{|c|c|c|}
\hline Object & Size $\mathrm{m}$ & Position $(\mathrm{x}, \mathrm{y}, \mathrm{z}) \mathrm{m}$ \\
\hline Inlet (door) & $4.68(\mathrm{~L}) \times 1.72(\mathrm{~W}) \mathrm{m}$ & $8.81,0,0$ \\
\hline Outlet (exhaust fan) & $(\mathrm{D}) 0.4 \mathrm{~m}$ & $3.08,1.7,0$ \\
\hline window & $2(\mathrm{~L}) \times 1.17(\mathrm{~W}) \mathrm{m}$ & $1.6,1,12$ \\
\hline Welding engine & $0.5(\mathrm{~L}) \times 0.5(\mathrm{~W}) \times 0.68(\mathrm{H}) \mathrm{m}$ & $1.625,0,10$ \\
\hline Table & $0.5(\mathrm{~L}) \times 0.5(\mathrm{~W}) \times 1(\mathrm{H}) \mathrm{m}$ & $0.625,0,10$ \\
\hline Cabin & $2(\mathrm{~L}) \times 2(\mathrm{H}) \mathrm{m}$ & $4.025,6,0$ \\
\hline Light & $0.3(\mathrm{~L}) \times 0.3(\mathrm{~W}) \times 0.3(\mathrm{H}) \mathrm{m}$ & \\
\hline
\end{tabular}

\subsection{Welding Workshop (empty-space case)}

As mentioned previously, at this case the welding workshop was empty. The dimensions and positions of the objects in the welding workshop are shown in the table (2), while the boundary conditions are shown on the Figure (7). In this case, only the 10 exhaust fans were operated and the fresh air entered to the workshop from the door, which kept open always at velocity $1.148 \mathrm{~m} / \mathrm{s}$, as shown in Figures (8) and (9). It should be noted that the model configurations were set so that the best balance is achieved among convergence, grid independency, and runtime saving, due to the high complexity of the domain geometry as can be shown in Figure (10). The numerical results are supported by experimental data which are listed in the table (3). The numerical computations are done using the ANSYS 15 program. A turbulent intensity of $5 \%$ is taken. The computations are represented by the distribution of air. After the experimental measurements and the numerical values are accomplished, which comprising, air velocity, temperature and relative humidity, it is shown that a good agreement when comparison between experimental data and numerical results, as given by the Figures. (11 and 12).

The temperature distribution contours are represented graphically as shown by Figure (13), while the velocity distribution contours are represented graphically as shown by Figure (14). The temperature of the inflow air in the workshop is $309.83 \mathrm{~K}$ and that of the region near the exhaust fan is $307 \mathrm{~K}$, while reach to a value of $317 \mathrm{~K}$ at the ceiling of the workshop and minimum value $303 \mathrm{~K}$ at the floor. It was 


\section{AL-QADISIYAH JOURNAL FOR ENGINEERING SCIENCES}

Vol. 11, No. 1

ISSN: 1998-4456

observed that the temperature differences are between (7-14K) in large welding workshop. It is observed that the air enters horizontally, moves straight and reaches to the north wall. Air flow strikes the north wall and bends downwards to form recirculation zone between the middle of the welding workshop and both the (west and east) walls. Velocity of the inlet air $(1.148 \mathrm{~m} / \mathrm{sec})$ is reduced and reaches to a minimum value at the stagnation point in the center of recirculation zone. It is observed that $\mathrm{CO}_{2}$ concentration is equal for all points in the workshop because the welding machines are not operated. Also CO concentration is equal to 0.0 because there is no source of pollutant in this case. As seen in the Figures 15 and 16. Also see the results in the Figure 17,18 and 19.

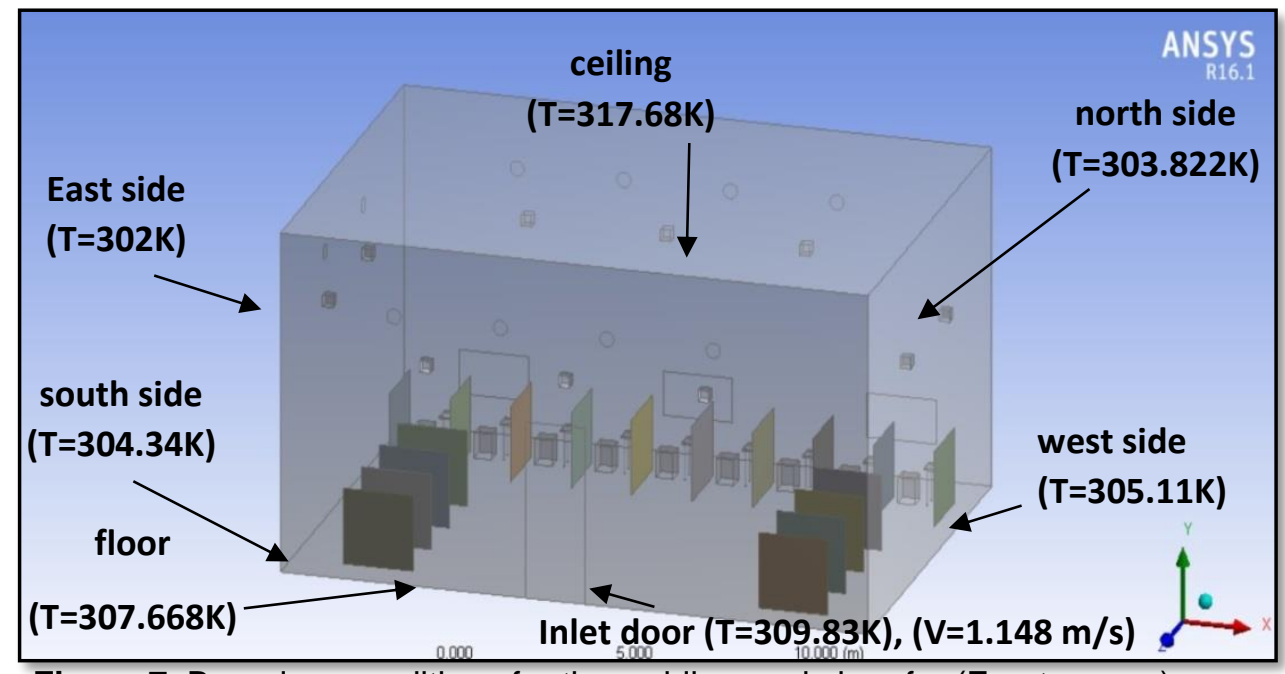

Figure 7. Boundary conditions for the welding workshop for (Empty- case)

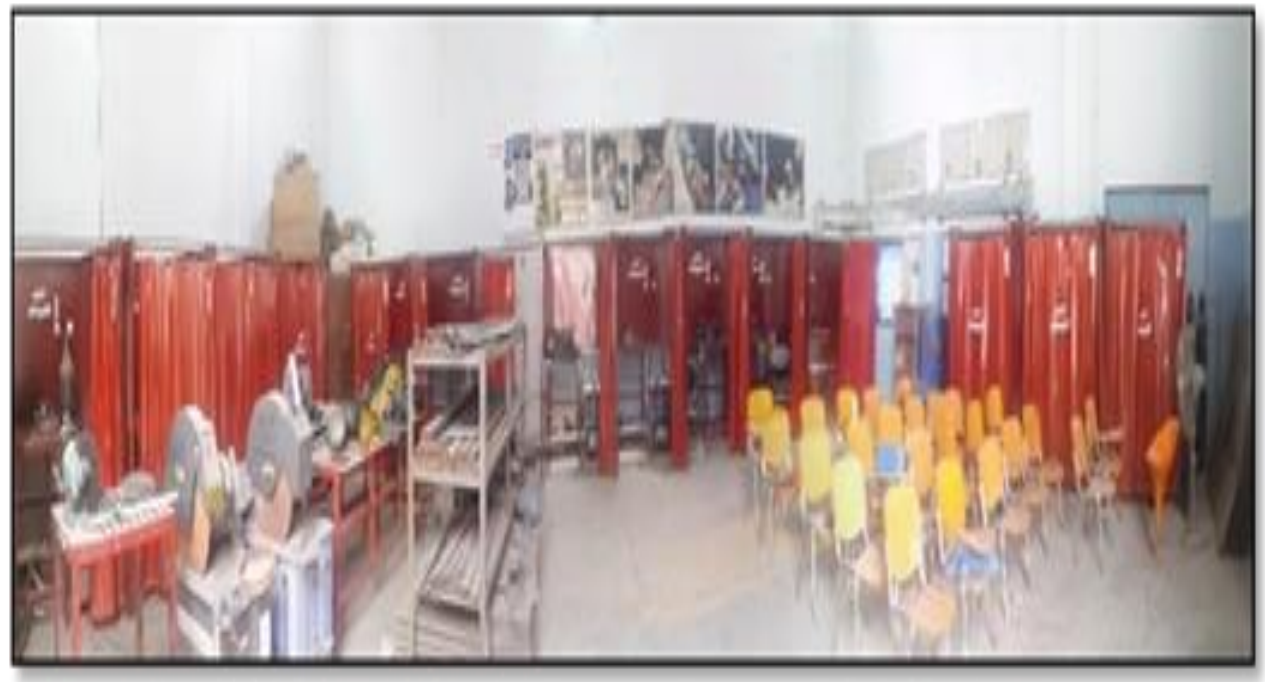

Figure 8: Real photo for (Empty-space case) 


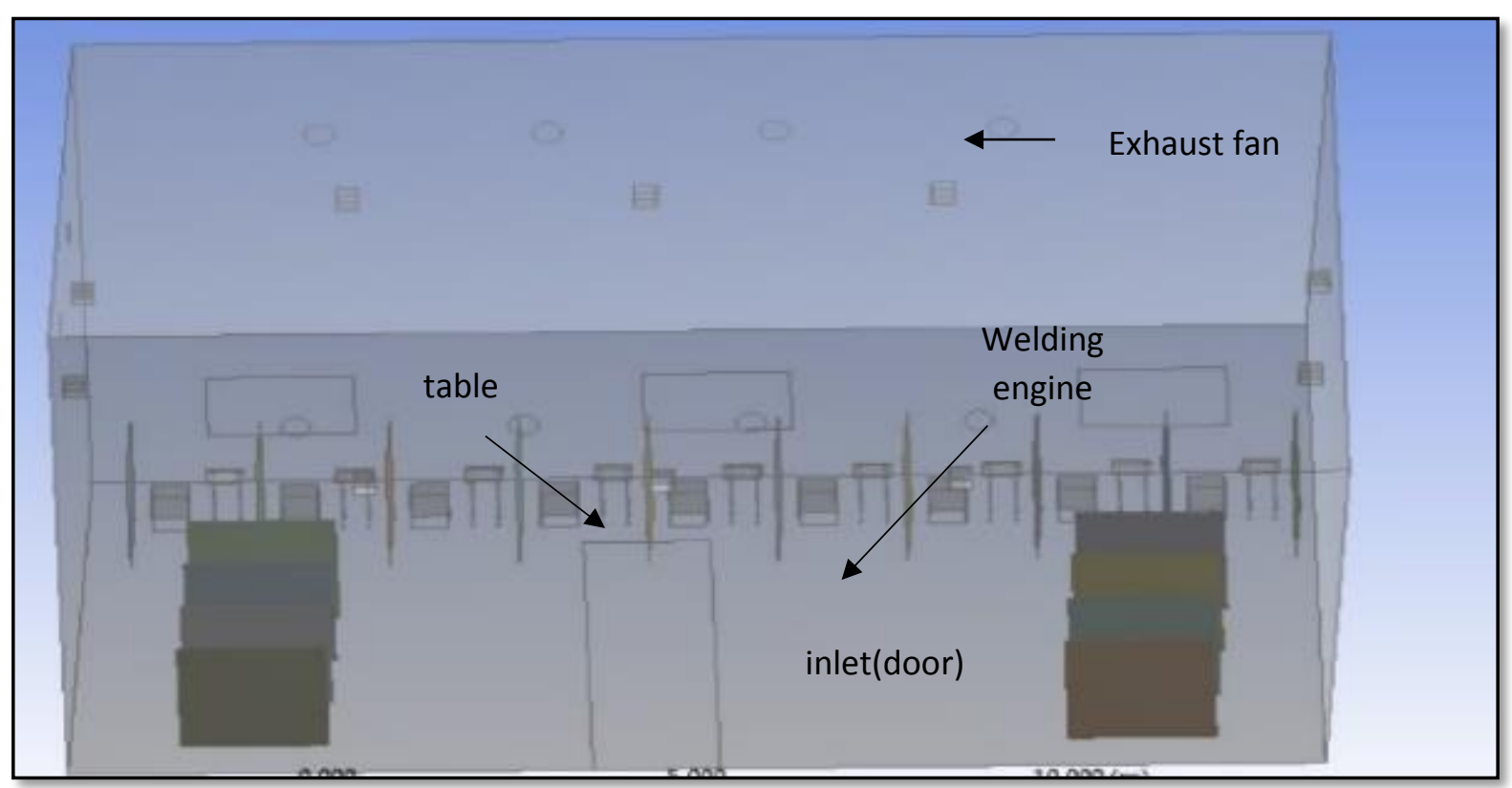

Figure 9: Domain whole for (Empty-space case)
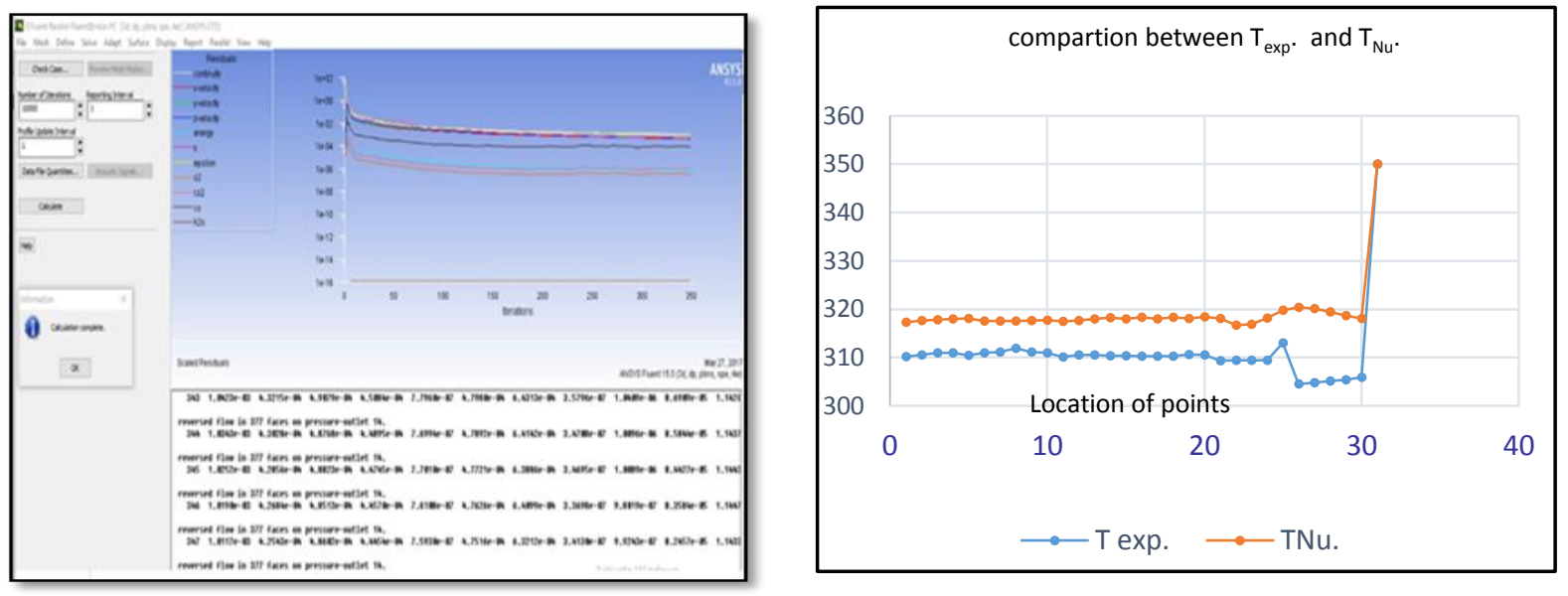

Figure. 10 Mesh Independent Study

compartion between $\mathrm{RH}_{\text {exp }}$. and $\mathrm{RH}_{\mathrm{Nu}}$.

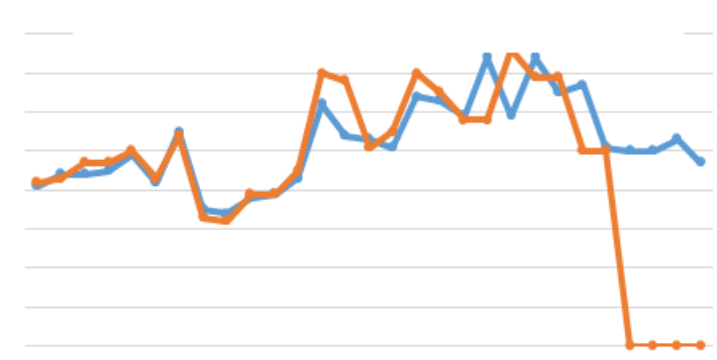

$\begin{array}{lllllllllllllll}1 & 3 & 5 & 7 & 9 & 11 & 13 & 15 & 17 & 19 & 21 & 23 & 25 & 27 & 29\end{array}$ Location of points RHEXP. RHNU.
Figure. 11 Comparison betweenT $T_{\text {exp. }} \& T_{\text {Nu. }}$. For Empty- case

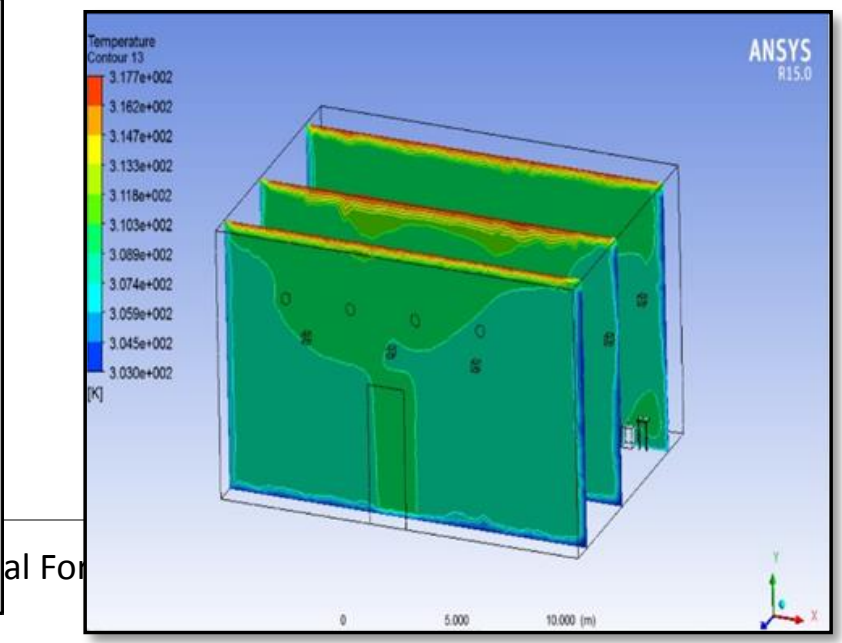

Figure 13: Temperature contour for empty case

Figure 12 : Comparison between 


\section{AL-QADISIYAH JOURNAL FOR ENGINEERING SCIENCES}

Vol. 11 , No. 1

ISSN: 1998-4456

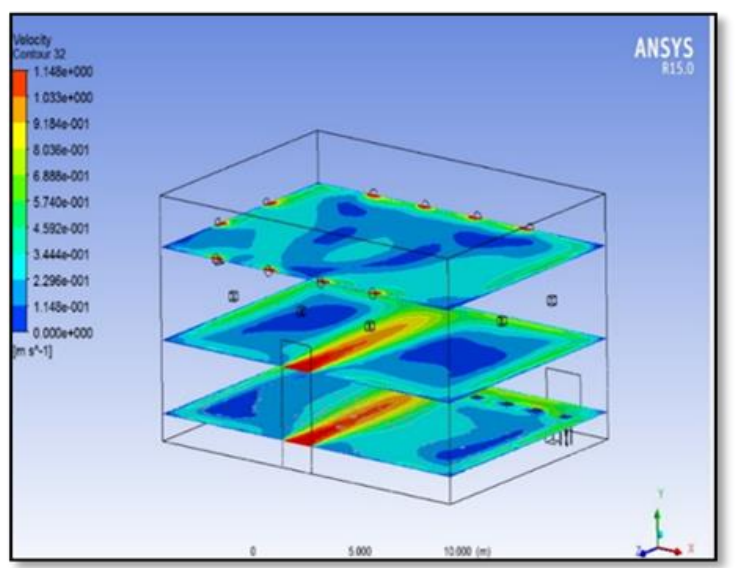

Figure 14 : Velocity contour for empty case

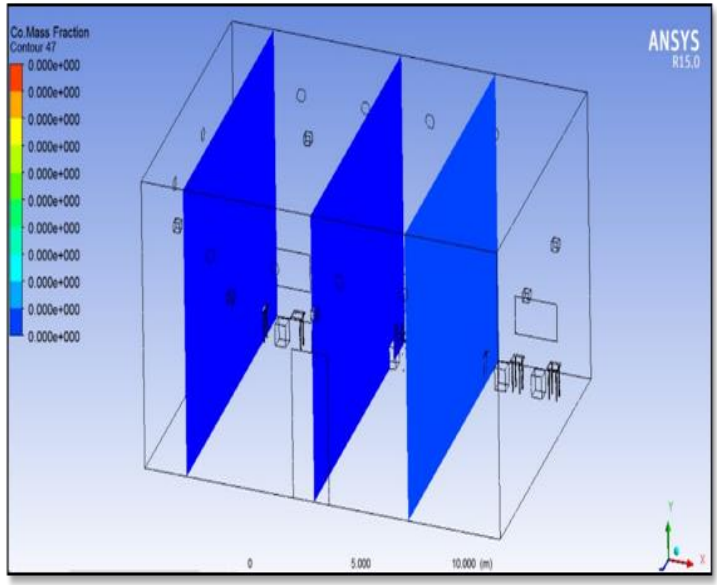

Figure 16 : CO concentration contour for empty case

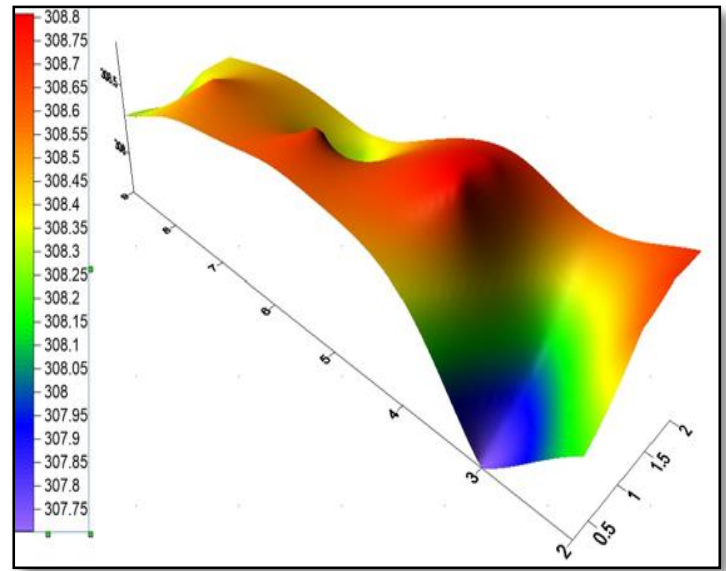

Figure $18: 3 \mathrm{D}$ Temperature distribution in the plane $y-z$ at $x=6.5 m$ for empty case

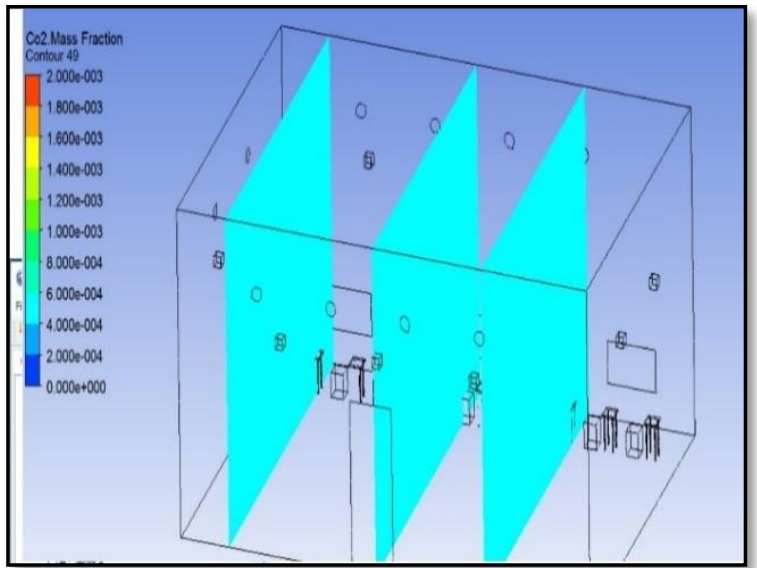

Figure $15: \mathrm{CO}_{2}$ concentration contour for empty case

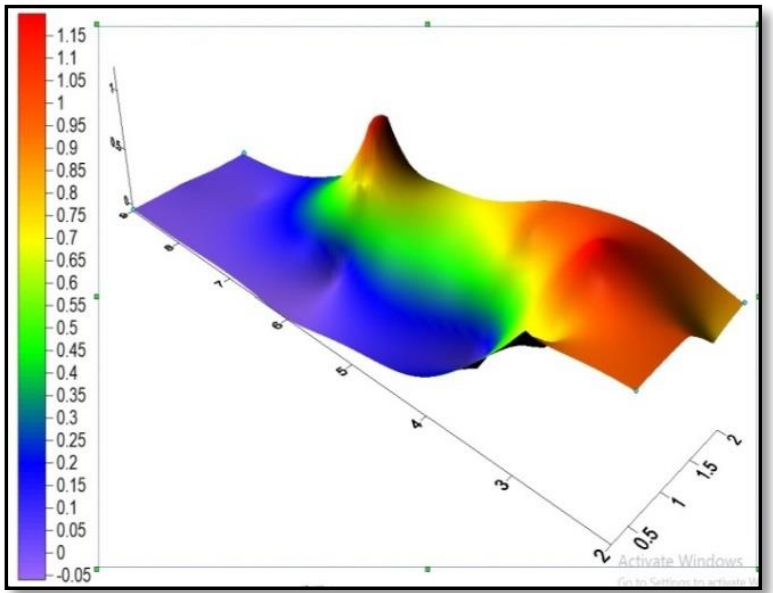

Figure $17: 3 \mathrm{D}$ velocity distribution in the plane $y-z$ at $x=6.5 m$ for empty case

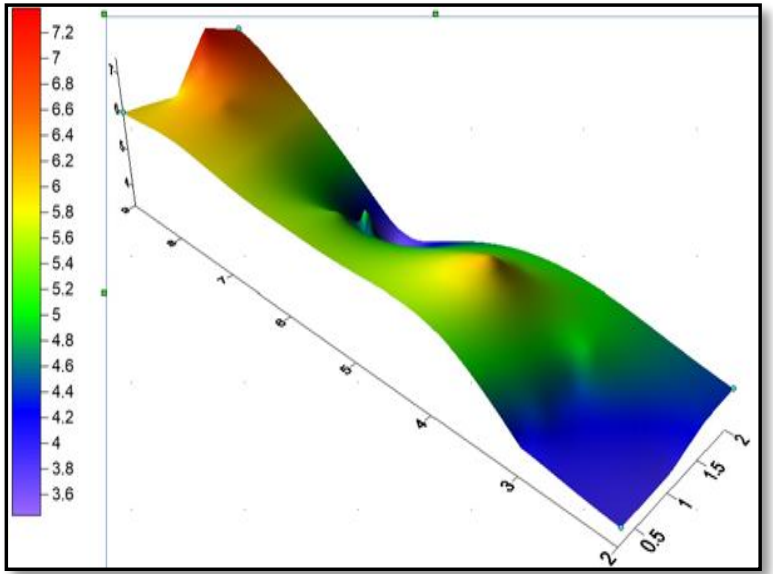

Figure 19: 3D Relative Humidity distribution in the plane $y-z$ at $x=6.5 m$ for empty case 


\section{AL-QADISIYAH JOURNAL FOR ENGINEERING SCIENCES}

Vol. 11 , No. 1

ISSN: $1998-4456$

Table 3: Measured and Numerical values of air velocity, temperature and relative humidity of the selected points of the domain in (empty-space case) at $\mathrm{V}=1.148 \mathrm{~m} / \mathrm{s}$

\begin{tabular}{|c|c|c|c|c|c|c|c|c|c|}
\hline \multirow{2}{*}{ Point } & \multicolumn{3}{|c|}{ Location } & \multirow{2}{*}{$\begin{array}{c}V_{\text {EXP. }} \\
\mathrm{m} / \mathrm{s}\end{array}$} & \multirow{2}{*}{$\begin{array}{l}\mathrm{V}_{\mathrm{NU}} \\
\mathrm{m} / \mathrm{s}\end{array}$} & \multirow{2}{*}{$\begin{array}{c}\text { TeXP. } \\
\mathrm{K}\end{array}$} & \multirow{2}{*}{$\begin{array}{c}T_{N U} . \\
K\end{array}$} & \multirow{2}{*}{$\underset{\%}{R H_{\text {EXP. }} .}$} & \multirow{2}{*}{$\begin{array}{c}\mathrm{RH}_{\mathrm{NU}} \\
\%\end{array}$} \\
\hline & $x$ & $Y$ & $z$ & & & & & & \\
\hline 1 & 6.5 & 0.25 & 3 & 0.95 & 0.649 & 307.7 & 308.78 & 4.1 & 4.2 \\
\hline 2 & 6.5 & 0.5 & 3 & 0.721 & 0.656 & 307.8 & 308.94 & 4.4 & 4.3 \\
\hline 3 & 6.5 & 0.75 & 3 & 0.771 & 0.669 & 307.9 & 309.03 & 4.4 & 4.7 \\
\hline 4 & 6.5 & 1 & 3 & 1.16 & 0.670 & 308.0 & 309.10 & 4.5 & 4.7 \\
\hline 5 & 6.5 & 1.2 & 3 & 1.208 & 0.682 & 308.1 & 309.14 & 4.9 & 5 \\
\hline 6 & 6.5 & 1.3 & 6 & 0.773 & 0.681 & 308.2 & 309.15 & 4.2 & 4.3 \\
\hline 7 & 6.5 & 1.4 & 6 & 0.606 & 0.670 & 308.3 & 309.17 & 5.5 & 5.4 \\
\hline 8 & 6.5 & 1.5 & 6 & 1.167 & 0.675 & 308.3 & 309.18 & 3.5 & 3.3 \\
\hline 9 & 6.5 & 1.75 & 6 & 1.160 & 0.673 & 308.3 & 309.22 & 3.4 & 3.2 \\
\hline 10 & 6.5 & 2 & 6 & 0.383 & 0.670 & 308.4 & 309.26 & 3.8 & 3.9 \\
\hline 11 & 9.5 & 1 & 2 & 1.001 & 0.560 & 308.6 & 308.904 & 3.9 & 3.9 \\
\hline 12 & 9.5 & 1.5 & 2 & 0.763 & 0.575 & 308.7 & 308.94 & 4.3 & 4.5 \\
\hline 13 & 9.5 & 1 & 4 & 0.0 & 0.515 & 308.8 & 308.56 & 6.2 & 7 \\
\hline 14 & 9.5 & 1.5 & 4 & 0.895 & 0.549 & 308.8 & 308.738 & 5.4 & 6.8 \\
\hline 15 & 9.5 & 1 & 6 & 0.0 & 0.520 & 308.7 & 308.471 & 5.3 & 5.1 \\
\hline 16 & 9.5 & 1.5 & 6 & 0.0 & 0.540 & 308.7 & 308.70 & 5.1 & 5.5 \\
\hline 17 & 9.5 & 1 & 8 & 0.0 & 0.488 & 308.6 & 308.422 & 6.4 & 7 \\
\hline 18 & 9.5 & 1.5 & 8 & 0.0 & 0.513 & 308.5 & 308.58 & 6.3 & 6.5 \\
\hline 19 & 9.5 & 1 & 9 & 0.0 & 0.412 & 308.2 & 308.36 & 5.9 & 5.8 \\
\hline 20 & 9.5 & 1.5 & 9 & 0.0 & 0.413 & 308.36 & 308.48 & 7.4 & 5.8 \\
\hline 21 & 1 & 1.5 & 7 & 0.0 & 0.144 & 308.3 & 308.33 & 5.9 & 7.6 \\
\hline 22 & 2 & 1.5 & 7 & 0.0 & 0.088 & 308.3 & 308.71 & 7.4 & 6.9 \\
\hline 23 & 3 & 1.5 & 7 & 0.0 & 0.119 & 308.3 & 308.91 & 6.5 & 6.9 \\
\hline 24 & 4 & 1.5 & 7 & 0.715 & 0.169 & 308.4 & 308.98 & 6.7 & 5 \\
\hline 25 & 5 & 1.5 & 7 & 0.849 & 0.228 & 308.3 & 308.94 & 5.1 & 5 \\
\hline 26 & 6 & 1.5 & 7 & 0.0 & 0.39 & 308.3 & 308.85 & 5.0 & 5 \\
\hline 27 & 7 & 1.5 & 7 & 0.0 & 0.87 & 308.5 & 309.25 & 5.0 & 5.1 \\
\hline 28 & 8 & 1.5 & 7 & 0.727 & 1.089 & 308.5 & 309.57 & 5.3 & 5.2 \\
\hline 29 & 9 & 1.5 & 7 & 0.843 & 0.763 & 308.4 & 309.02 & 4.7 & 4.9 \\
\hline 30 & 10 & 1.5 & 7 & 0.0 & 0.367 & 308.5 & 308.49 & 5.3 & 5.1 \\
\hline
\end{tabular}

\subsection{Welding Workshop (Full-space case)}

This is the main case-study in this research work, where the welding workshop is full of 35 students and 3 trainers, as detailed previously, all 15 welding machines are operated by 15 students, the 10 exhaust fans were operated also and the fresh air entered to the workshop from the inlet door at velocity 0 . $8675 \mathrm{~m} / \mathrm{s}$, as shown in the Figures (20 and 21). The boundary conditions of this case are given in the Figure (22). The numerical results of the ANSYS 15 program includes the distribution of indoor air velocity, 


\section{AL-QADISIYAH JOURNAL FOR ENGINEERING SCIENCES}

Vol. 11, No. 1

ISSN: $1998-4456$

temperature, and relative humidity, also supported with some experimental measurements, as given in the table (4). After the experimental measurements and the numerical values are accomplished it is shown that a good agreement when comparison between experimental data and numerical result, as given by the Figures (23 and 24).

The temperature of the inflow air in the workshop is $308.97 \mathrm{~K}$ and that of the region near the exhaust fan is $317 \mathrm{~K}$, while reach to a value of $325 \mathrm{~K}$ at the ceiling of the workshop and minimum value $306 \mathrm{~K}$ at the floor. It was observed that the temperature differences are between (7-16K) in large welding workshop as shown in Figure (25). The air stream passes through the whole of the workshop and strikes the north wall to form recirculation zone at low temperature, while the temperature will increase to the value of $325 \mathrm{~K}$ at the zone near ceiling and around the students. The computed distributions of velocity contour in the welding workshop are illustrated in Figure (26). The recirculation zone is formed between the middle of the workshop and both the east and west walls where the value of velocity is $0.08 \mathrm{~m} / \mathrm{s}$. The air velocity is observed to be maximum at the region near the exhaust fan.

The distribution of the $\mathrm{CO}_{2}$ concentration is shown in Figure (27). These concentrations which obtained from numerical study and with supported by experimental measurement, are found to be higher than those observed in the previous case, because all the welding machines are operated by the students under training. It is observed that the mass fraction of $\mathrm{CO}_{2}$ at the inlet was 0.2073 , and at region near the welding machines increases to 0.213 , while a maximum value of 0.219 was found to be at ceiling. Measurements of concentration of carbon monoxide $\mathrm{CO}$ in the welding workshop shows that an average value of CO concentration was $41.71 \mathrm{ppm}$, as given by Figure (28), while as shown in the Figure (29), the maximum allowable concentration of $\mathrm{CO}$ must not exceed a value of $35 \mathrm{ppm}$ per one-hour direct exposure as given by (Iraqi Standard for ambient air quality)[10]. This high concentration led to harmful effects on the workshop occupations. The numerical results and experimental measurements of $\mathrm{CO}$ and $\mathrm{CO}_{2}$ concentrations are given in the Table (5). It must be known that the air change per hour (ACH) equal 13, while according to correct engineering manner, $\mathrm{ACH}$ must be equal to 20,[11]. So this is the reason that lead to increase the pollutants in the welding workshop. The contaminant removal effectiveness (CRE) for this case is equal to 0.125 , and this value is low because of focus of pollutants inside welding workshop. CRE can be calculated from equation ( 11 ). Also some results are given in the figures 30,31 and 32 .

$$
C R E=\frac{C_{e}}{C_{B Z}} \quad \text { (11) [12] }
$$




\section{AL-QADISIYAH JOURNAL FOR ENGINEERING SCIENCES}

Vol. 11 , No. 1

ISSN: $1998-4456$

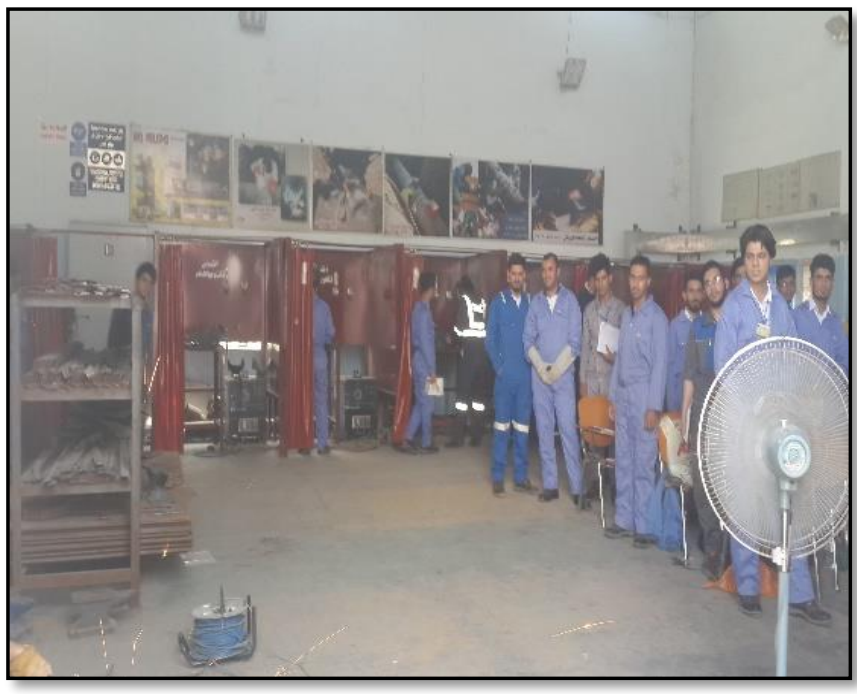

Figure 20: Real photo for (Full-space case)

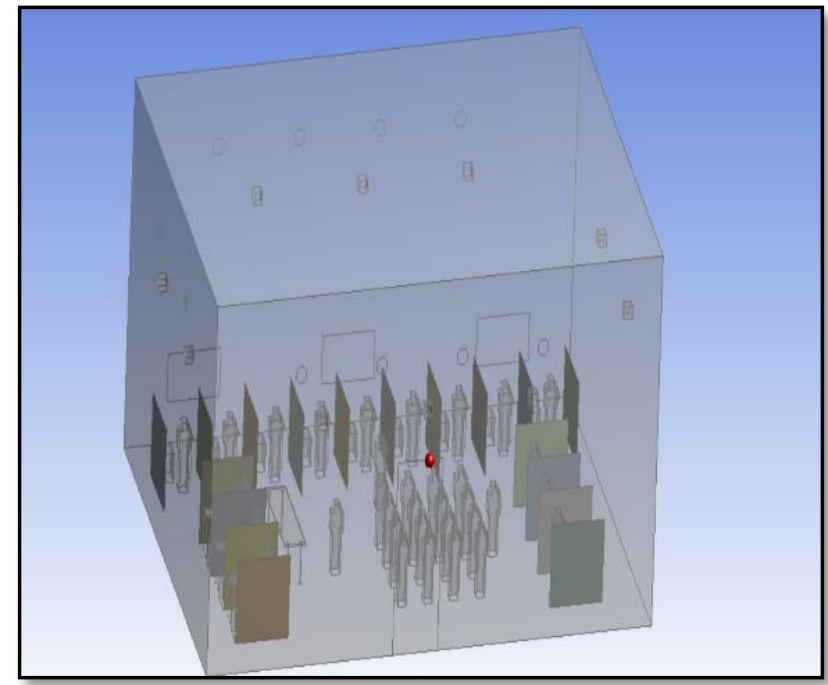

Figure 21: Domain whole for (Full-space case)

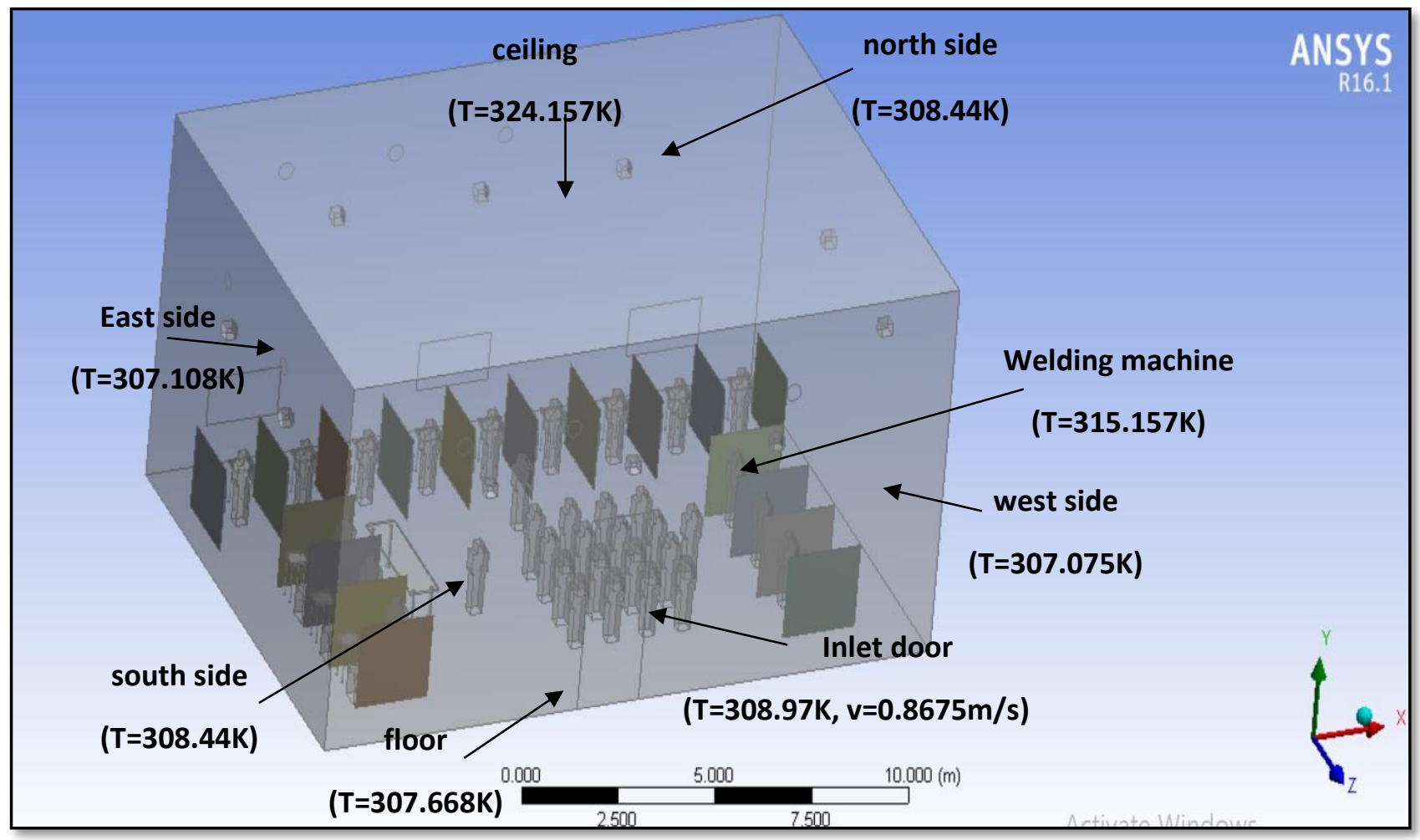

Figure 22. Boundary conditions for the welding workshop for (Full- case) 


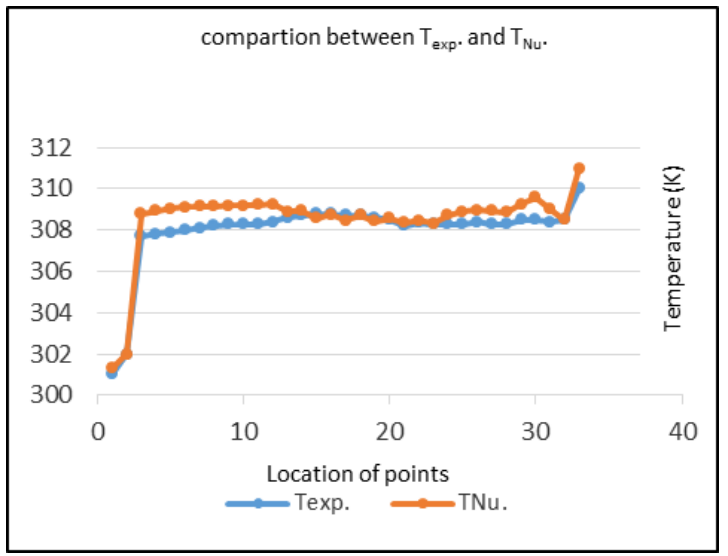

Figure 23: Comparison between $T_{\exp } \& T_{N u}$.

For Full-space case

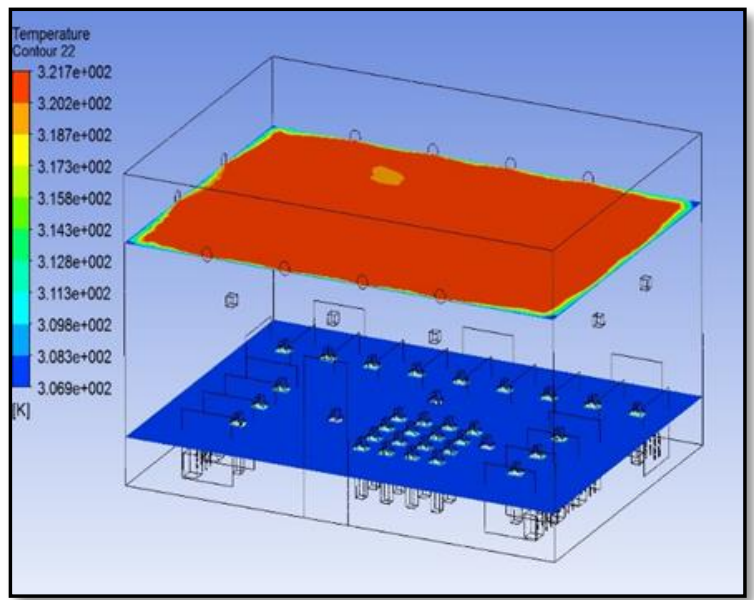

Figure 25: Temperature contour for full case

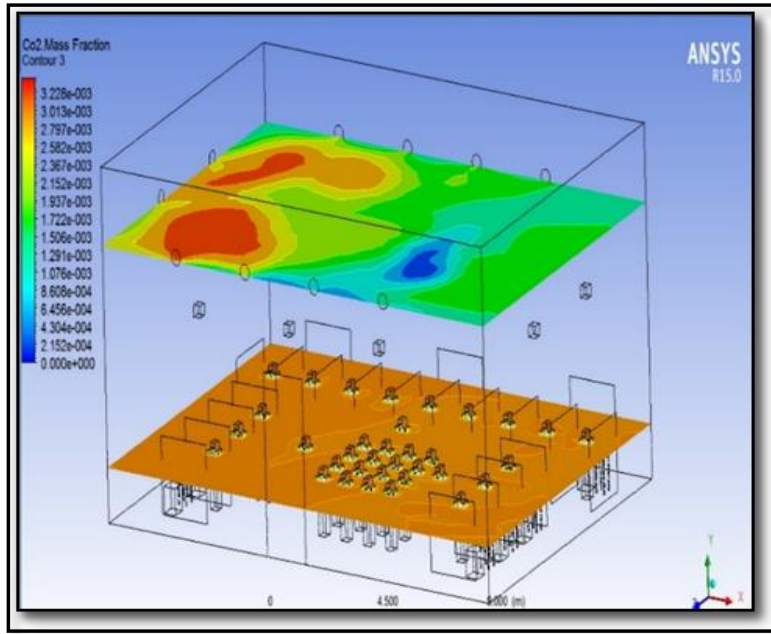

Figure 27 :CO2 concentration contour for full case case

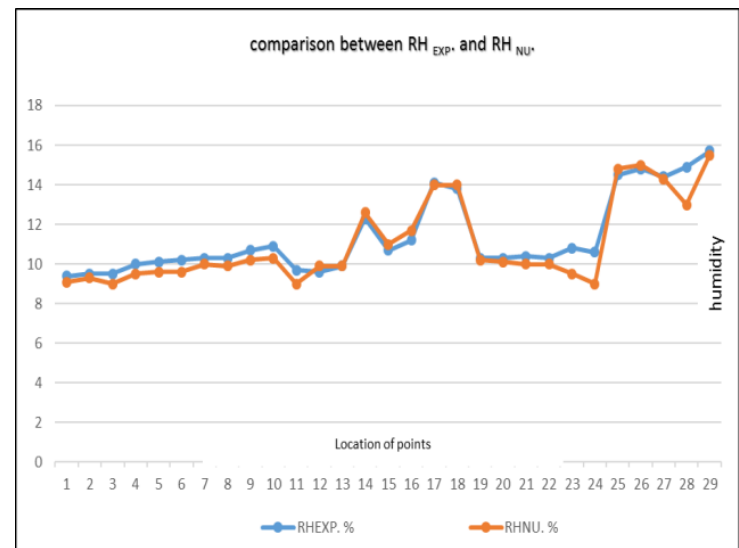

Figure 24 :Comparison between $\mathrm{RH}_{\exp } \& \mathrm{RH}_{\mathrm{Nu}}$ For Full-space case

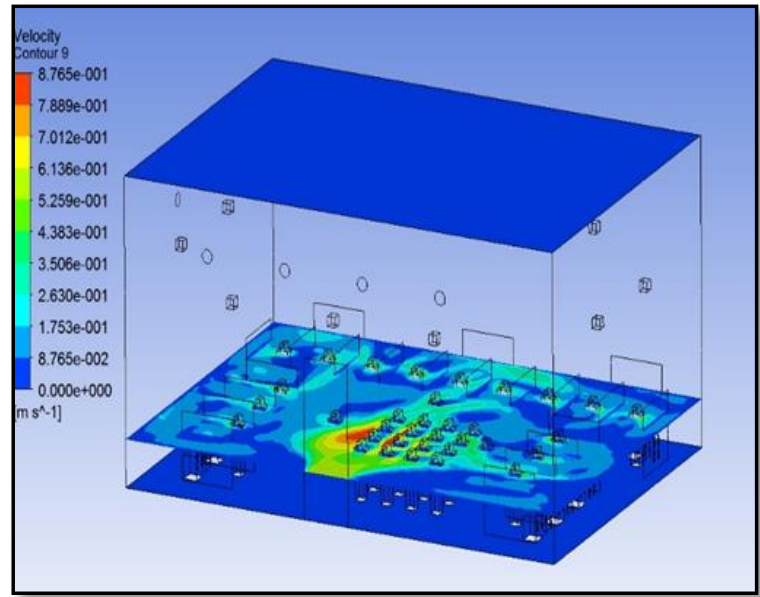

Figure 26: Velocity contour for full case

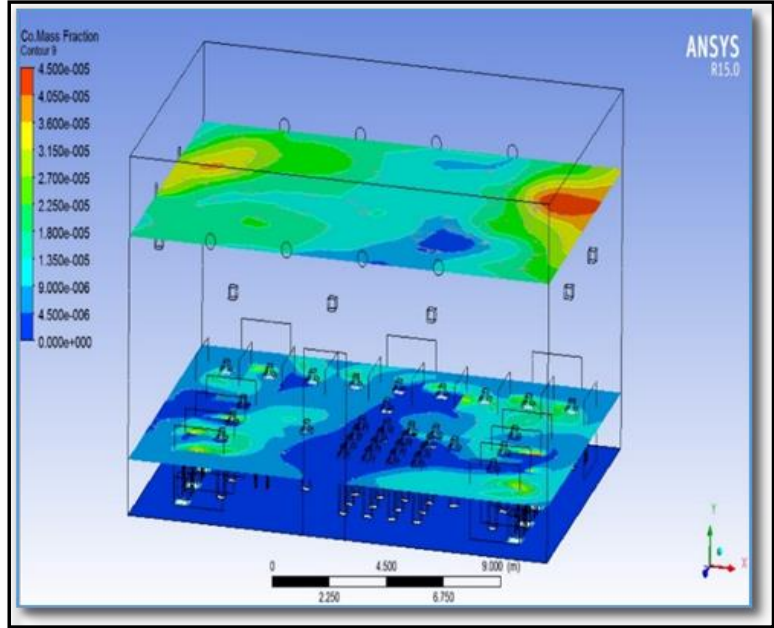

Figure 28: $\mathrm{CO}$ concentration contour for full 


\section{AL-QADISIYAH JOURNAL FOR ENGINEERING SCIENCES}

Vol. 11, No. 1

ISSN: 1998-4456

\begin{tabular}{|c|c|c|c|c|c|}
\hline $\begin{array}{l}\mathbf{N} \\
\text { o. }\end{array}$ & pollutants & $\begin{array}{l}\text { Measureme } \\
\text { nt period }\end{array}$ & $\begin{array}{l}\text { Ambient } \\
\text { Air } \\
\text { standard( } \\
\text { ppm) }\end{array}$ & $\begin{array}{c}\text { Ambien } \\
\text { t Air } \\
\text { standar } \\
d\left(\mu g / m^{s}\right)\end{array}$ & $\begin{array}{l}\text { Standard analysis } \\
\text { method }\end{array}$ \\
\hline 1 & $\begin{array}{l}\text { Sulfur } \\
\text { dioxide(SO } \\
\text { 2) }\end{array}$ & $\begin{array}{l}1 \text { hour } \\
24 \text { hour } \\
1 \text { year }\end{array}$ & $\begin{array}{l}0.1 \\
0.04 \\
0.018\end{array}$ & & UV Fluorescent \\
\hline 2 & $\begin{array}{l}\text { Carbon } \\
\text { Monoxide } \\
\text { (CO) }\end{array}$ & $\begin{array}{l}8 \text { hour } \\
1 \text { hour }\end{array}$ & $\begin{array}{l}10 \\
35\end{array}$ & & $\begin{array}{l}\text { IR Gas filter } \\
\text { correlation }\end{array}$ \\
\hline 3 & $\begin{array}{l}\text { Nitrogen } \\
\text { Dioxide } \\
\left(\mathrm{NO}_{2}\right)\end{array}$ & $\begin{array}{l}24 \text { hour } \\
1 \text { year }\end{array}$ & $\begin{array}{l}0.05 \\
0.04\end{array}$ & & Chemiluminescence \\
\hline
\end{tabular}

Figure 29 Iraqi standard for Ambient Air Quality[10]

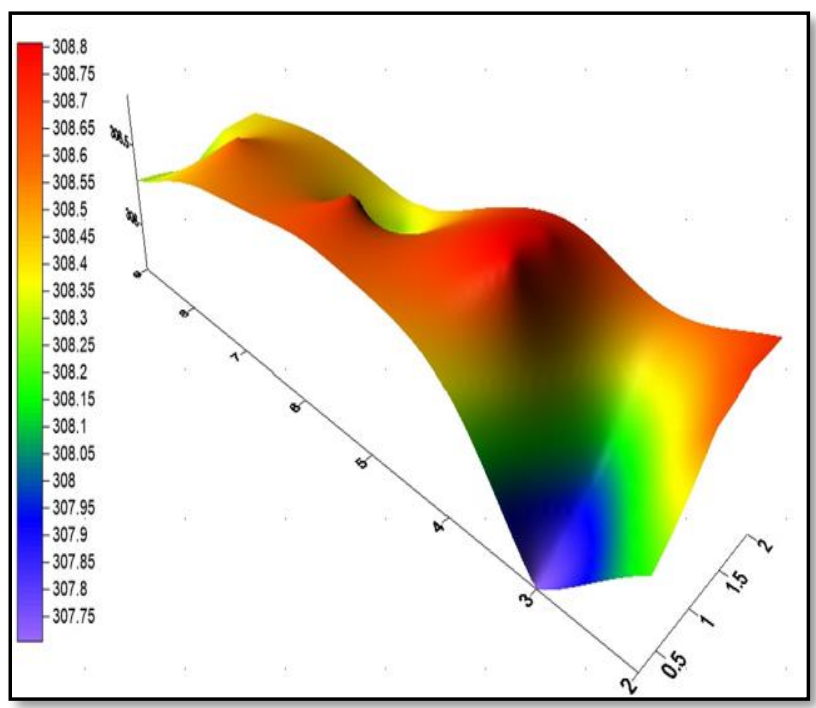

Figure 31: 3D temperature distribution in the plane $y-z$ at $x=6.5 m$ for empty case

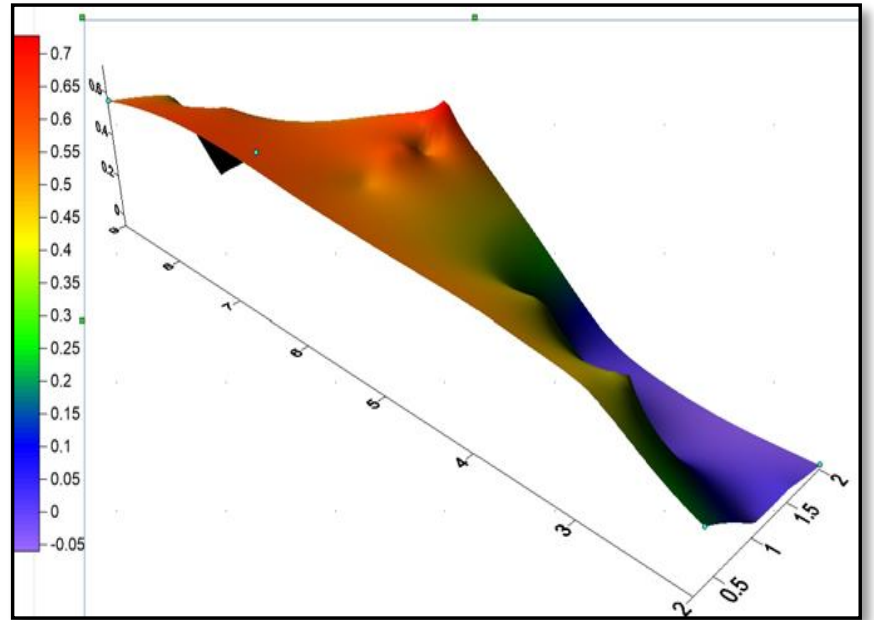

Figure $30: 3 D$ velocity distribution in the plane $y-z$ at $x=6.5 m$ for Full case

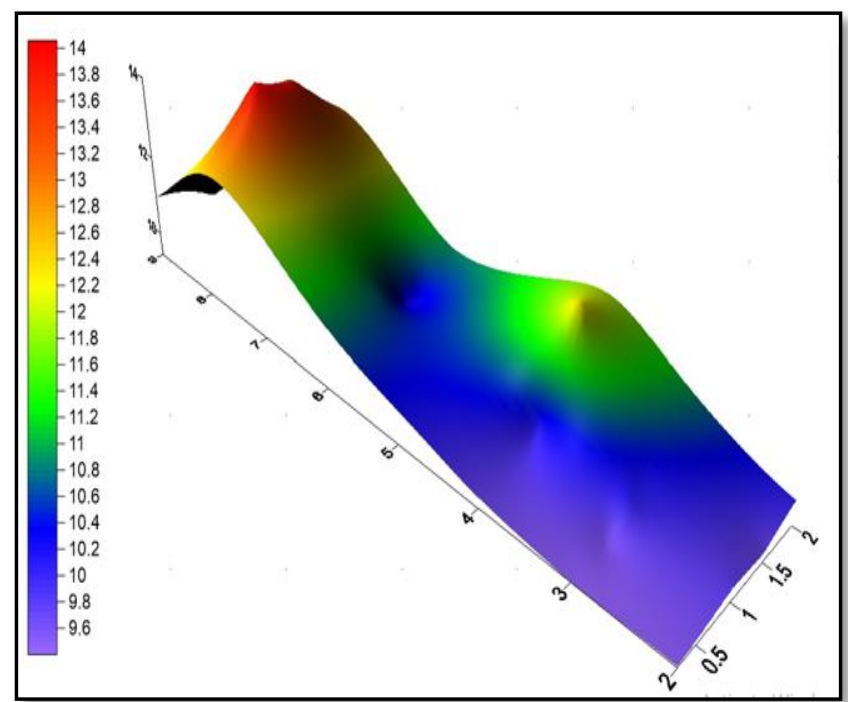

Figure 32 :3D Relative humidity in plane $y-z$ at $\mathrm{x}=6.5 \mathrm{~m}$ for empty 
AL-QADISIYAH JOURNAL FOR ENGINEERING SCIENCES
Vol. 11 , No. 1

ISSN: $1998-4456$

Table 4: Measured and Numerical values of air velocity, temperature and relative humidity of the selected points of the domain in (Full-space case) at $\mathrm{V}=0.8679 \mathrm{~m} / \mathrm{s}$

\begin{tabular}{|c|c|c|c|c|c|c|c|c|c|}
\hline \multirow{3}{*}{ Point } & \multicolumn{3}{|c|}{ Location } & \multirow{3}{*}{$\begin{array}{c}V_{\text {EXP. }} \\
\mathrm{m} / \mathrm{s}\end{array}$} & \multirow{3}{*}{$\begin{array}{l}\mathrm{V}_{\mathrm{NU}} . \\
\mathrm{m} / \mathrm{s}\end{array}$} & \multirow{3}{*}{$\begin{array}{c}\text { TEXP. } \\
\mathrm{K}\end{array}$} & \multirow{3}{*}{$\begin{array}{c}\mathrm{T}_{\mathrm{Nu}} . \\
\mathrm{k}\end{array}$} & \multirow{3}{*}{$\begin{array}{c}R H_{\text {EXP. }} . \\
\%\end{array}$} & \multirow{3}{*}{$\begin{array}{c}\mathrm{R} \mathrm{H}_{\mathrm{NU}} . \\
\%\end{array}$} \\
\hline & & & & & & & & & \\
\hline & $x$ & Y & Z & & & & & & \\
\hline 1 & 6.5 & 0.25 & 3 & 0.455 & 0.46908 & 310.22 & 317.32 & 9.4 & 9.1 \\
\hline 2 & 6.5 & 0.5 & 3 & 0.423 & 0.427642 & 310.54 & 317.611 & 9.5 & 9.3 \\
\hline 3 & 6.5 & 0.75 & 3 & 0.400 & 0.398835 & 310.98 & 317.794 & 9.5 & 9 \\
\hline 4 & 6.5 & 1 & 3 & 0.0 & 0.38557 & 310.99 & 317.958 & 10 & 9.5 \\
\hline 5 & 6.5 & 1.2 & 3 & 0.0 & 0.383982 & 310.44 & 318.064 & 10.1 & 9.6 \\
\hline 6 & 6.5 & 1.3 & 6 & 0.601 & 0.614679 & 310.98 & 317.533 & 10.2 & 9.6 \\
\hline 7 & 6.5 & 1.4 & 6 & 0.598 & 0.631818 & 311.12 & 317.563 & 10.3 & 10 \\
\hline 8 & 6.5 & 1.5 & 6 & 0.611 & 0.645787 & 311.94 & 317.593 & 10.3 & 9.9 \\
\hline 9 & 6.5 & 1.75 & 6 & 0.525 & 0.674855 & 311.109 & 317.674 & 10.7 & 10.2 \\
\hline 10 & 6.5 & 2 & 6 & 0.743 & 0.695179 & 310.956 & 317.754 & 10.9 & 10.3 \\
\hline 11 & 9.5 & 1 & 2 & 0.0 & 0.374653 & 310.1 & 317.502 & 9.7 & 9 \\
\hline 12 & 9.5 & 1.5 & 2 & 0.0 & 0.380193 & 310.5 & 317.683 & 9.6 & 9.9 \\
\hline 13 & 9.5 & 1 & 4 & 0.411 & 0.47413 & 310.5 & 317.954 & 9.9 & 9.9 \\
\hline 14 & 9.5 & 1.5 & 4 & 0.0 & 0.403288 & 310.4 & 318.23 & 12.3 & 12.6 \\
\hline 15 & 9.5 & 1 & 6 & 0.523 & 0.673751 & 310.4 & 318.02 & 10.7 & 11 \\
\hline 16 & 9.5 & 1.5 & 6 & 0.421 & 0.481684 & 310.3 & 318.361 & 11.2 & 11.7 \\
\hline 17 & 9.5 & 1 & 8 & 0.567 & 0.581161 & 310.3 & 318.01 & 14.1 & 14 \\
\hline 18 & 9.5 & 1.5 & 8 & 0.401 & 0.419516 & 310.3 & 318.362 & 13.8 & 14 \\
\hline 19 & 9.5 & 1 & 9 & 0.489 & 0.507936 & 310.6 & 318.06 & 10.3 & 10.2 \\
\hline 20 & 9.5 & 1.5 & 9 & 0.0 & 0.30326 & 310.5 & 318.378 & 10.3 & 10.1 \\
\hline 21 & 1 & 1.5 & 7 & 0.0 & 0.070 & 309.3 & 318.077 & 10.4 & 10 \\
\hline 22 & 2 & 1.5 & 7 & 0.0 & 0.218 & 309.4 & 316.699 & 10.3 & 10 \\
\hline 23 & 3 & 1.5 & 7 & 0.0 & 0.260 & 309.4 & 316.88 & 10.8 & 9.5 \\
\hline 24 & 4 & 1.5 & 7 & 0.0 & 0.33 & 309.4 & 318.146 & 10.6 & 9 \\
\hline 25 & 5 & 1.5 & 7 & 0.0 & 0.35 & 313 & 319.764 & 14.5 & 14.8 \\
\hline 26 & 6 & 1.5 & 7 & 0.0 & 0.31 & 304.5 & 320.426 & 14.8 & 15 \\
\hline
\end{tabular}


AL-QADISIYAH JOURNAL FOR ENGINEERING SCIENCES
Vol. 11 , No. 1

ISSN: $1998-4456$

\begin{tabular}{|c|c|c|c|c|c|c|c|c|c|}
\hline 27 & 7 & 1.5 & 7 & 0.0 & 0.39 & 304.8 & 320.142 & 14.4 & 14.3 \\
\hline 28 & 8 & 1.5 & 7 & 0.401 & 0.45 & 305.1 & 319.404 & 14.9 & 13 \\
\hline 29 & 9 & 1.5 & 7 & 0.0 & 0.06 & 305.4 & 318.701 & 15.7 & 15.5 \\
\hline 30 & 10 & 1.5 & 7 & 0.401 & 0.46 & 305.9 & 318.032 & 13.6 & 14 \\
\hline
\end{tabular}

Table 5: Measured and Numerical values of concentration of $\mathrm{CO}$ and $\mathrm{CO}_{2}$ of the selected points of the domain in Full-space case at $\mathrm{V}=0.8679 \mathrm{~m} / \mathrm{s}$

\begin{tabular}{|c|c|c|c|c|c|c|c|}
\hline \multirow{2}{*}{$\begin{array}{c}\text { Poi } \\
\text { nt }\end{array}$} & \multicolumn{2}{|c|}{ Location } & \multicolumn{2}{c|}{ Numerical } & \multicolumn{2}{c|}{ Experimental } \\
\cline { 2 - 8 } & $\mathrm{X}$ & $\mathrm{Y}$ & $\mathrm{Z}$ & $\begin{array}{c}\text { CO } \\
\text { concentration } \\
\text { (mass fraction) }\end{array}$ & $\begin{array}{c}\mathrm{CO}_{2} \\
\text { concentration } \\
\text { (mass fraction) }\end{array}$ & $\begin{array}{c}\text { CO } \\
\text { concentration } \\
\text { (mass fraction) }\end{array}$ & $\begin{array}{c}\mathrm{CO}_{2} \\
\text { concentration } \\
\text { (mass fraction) }\end{array}$ \\
\hline 1 & 6.5 & 0.25 & 3 & $5.163 \mathrm{e}-005$ & 0.00298044 & $5.45 \mathrm{e}-005$ & 0.0031 \\
\hline 2 & 6.5 & 0.5 & 3 & $5.2027 \mathrm{e}-005$ & 0.00297633 & $5.11 \mathrm{e}-005$ & 0.0031 \\
\hline 3 & 6.5 & 0.75 & 3 & $5.26863 \mathrm{e}-005$ & 0.00297444 & $5.876 \mathrm{e}-005$ & 0.0036 \\
\hline 4 & 6.5 & 1 & 3 & $5.35117 \mathrm{e}-005$ & 0.00297314 & $4.89 \mathrm{e}-005$ & 0.0039 \\
\hline 5 & 6.5 & 1.2 & 3 & $5.42215 \mathrm{e}-005$ & 0.00297063 & $5.115 \mathrm{e}-005$ & 0.0034 \\
\hline 6 & 6.5 & 1.3 & 6 & $5.46209 \mathrm{e}-005$ & 0.0029286 & $5.4609 \mathrm{e}-005$ & 0.0041 \\
\hline 7 & 6.5 & 1.4 & 6 & $5.50175 \mathrm{e}-005$ & 0.00296415 & $4.92 \mathrm{e}-005$ & 0.0044 \\
\hline 8 & 6.5 & 1.5 & 6 & $5.54175 \mathrm{e}-005$ & 0.00296534 & $5.36 \mathrm{e}-005$ & 0.0045 \\
\hline 9 & 6.5 & 1.75 & 6 & $5.63282 \mathrm{e}-005$ & 0.00296858 & $5.22 \mathrm{e}-005$ & 0.0048 \\
\hline 10 & 6.5 & 2 & 6 & $5.72694 \mathrm{e}-005$ & 0.00296858 & $3.794 \mathrm{e}-005$ & 0.0049 \\
\hline 11 & 9.5 & 1 & 2 & 0.000126987 & 0.00294657 & 0.0 & 0.005 \\
\hline 12 & 9.5 & 1.5 & 2 & 0.000100283 & 0.0029444 & 0.0 & 0.0044 \\
\hline 13 & 9.5 & 1 & 4 & $6.12252 \mathrm{e}-005$ & 0.00294848 & $5.15 \mathrm{e}-005$ & 0.0046 \\
\hline 14 & 9.5 & 1.5 & 4 & $6.83082 \mathrm{e}-005$ & 0.00292142 & $6.12 \mathrm{e}-005$ & 0.0032 \\
\hline 15 & 9.5 & 1 & 6 & $6.1497 \mathrm{e}-005$ & 0.00291825 & $4.18 \mathrm{e}-005$ & 0.0053 \\
\hline 16 & 9.5 & 1.5 & 6 & $6.7434 \mathrm{e}-005$ & 0.00296858 & $3.72 \mathrm{e}-005$ & 0.0029 \\
\hline 17 & 9.5 & 1 & 8 & $5.77645 \mathrm{e}-005$ & 0.00295204 & $5.24 \mathrm{e}-005$ & 0.0048 \\
\hline 18 & 9.5 & 1.5 & 8 & $6.1665 \mathrm{e}-005$ & 0.00296071 & $6.0 \mathrm{e}-005$ & 0.0037 \\
\hline 19 & 9.5 & 1 & 9 & $5.47906 \mathrm{e}-005$ & 0.00295109 & $5.25 \mathrm{e}-005$ & 0.0045 \\
\hline 20 & 9.5 & 1.5 & 9 & $5.75872 \mathrm{e}-005$ & 0.0029623 & $5.68 \mathrm{e}-005$ & 0.0034 \\
\hline & & & & & & & \\
\hline
\end{tabular}


AL-QADISIYAH JOURNAL FOR ENGINEERING SCIENCES
Vol. 11 , No. 1

ISSN: $1998-4456$

\begin{tabular}{|c|c|c|c|c|c|c|c|}
\hline 21 & 1 & 1.5 & 7 & $5.56633 \mathrm{e}-005$ & 0.00297949 & $5.13 \mathrm{e}-005$ & 0.0039 \\
\hline 22 & 2 & 1.5 & 7 & $5.56073 \mathrm{e}-005$ & 0.00297887 & $4.23 \mathrm{e}-005$ & 0.004 \\
\hline 23 & 3 & 1.5 & 7 & $5.56073 \mathrm{e}-005$ & 0.00296858 & $5.22 \mathrm{e}-005$ & 0.004 \\
\hline 24 & 4 & 1.5 & 7 & $4.75542 \mathrm{e}-005$ & 0.00298106 & $5.11 \mathrm{e}-005$ & 0.0078 \\
\hline 25 & 5 & 1.5 & 7 & $4.59234 \mathrm{e}-005$ & 0.00296858 & $4.90 \mathrm{e}-005$ & 0.0035 \\
\hline 26 & 6 & 1.5 & 7 & $4.70392 \mathrm{e}-005$ & 0.00297714 & $4.12 \mathrm{e}-005$ & 0.004 \\
\hline 27 & 7 & 1.5 & 7 & $5.10804 \mathrm{e}-005$ & 0.00296858 & $5.904 \mathrm{e}-005$ & 0.0046 \\
\hline 28 & 8 & 1.5 & 7 & $5.78112 \mathrm{e}-005$ & 0.00293522 & $4.72 \mathrm{e}-005$ & 0.0048 \\
\hline 29 & 9 & 1.5 & 7 & $6.34983 \mathrm{e}-005$ & 0.0029243 & $6.3498 \mathrm{e}-005$ & 0.0049 \\
\hline 30 & 10 & 1.5 & 7 & $6.4175 \mathrm{e}-005$ & 0.00290483 & $6.4175 \mathrm{e}-005$ & 0.005 \\
\cline { 2 - 7 }
\end{tabular}

\section{CONCLUSIONS AND RECOMMENDATIONS}

From the results obtained in this study, the following conclusions can be made:

1- The results of this research work show that the indoor environment of the welding workshop is highly polluted with $\mathrm{CO}_{2}$ and $\mathrm{CO}$ gases. These gases need to be treated, so that a healthy atmosphere is acquired.

2- The average air velocities provided by the existed ventilation system of the welding workshop is low, and this value is not enough to pull out the necessary percentage of harmful pollutants.

3- It can be observed from the temperature distribution in the welding workshop that, the higher temperatures are existed near the training students and in the region adjacent to the ceiling because of the heat released from the welding machines and the ceiling lights respectively.

4- The air change per hour $(\mathrm{ACH})$ has an important effect on the concentration of $\mathrm{CO}, \mathrm{CO}_{2}$ gases, and this factor will be studied in the compliment of this research work. A correct selected value of $\mathrm{ACH}$ will enhance the contaminate removal effectiveness (CRE).

5- It is recommended for the Basra Oil Training Institute, that the air change per hour of the welding workshop must be increased according to an engineering manner by adding some extra exhaust fans to the workshop, in order that the contaminate removal effectiveness will be enhanced more. 


\section{REFERENCES}

1. Abduljabbar, M., A., Mukhtar A., and Abdur, R., Effect of Size of Heated Obstruction within Room on Three Dimensional Air Flow Characteristics, American J. of Engineering and Applied Sciences 3 (2), 2010,pg. 372-379.

2. Khanooba, M, R, Numerical and Experimental Study of the best Air Conditioning System of a Large Athletic Hall (Wrestling Hall), M.S.C Thesis, The College Of Engineering University Of Basra, 2015.

3. Abdul Rahman I., Pratama Putra J.C., Asmi A., Modelling of Particle Dispersion in Mechanically Ventilated Space, Canadian Center of Science and Education, 2014.

4. G. Buonanno ,n, L.Morawska, Stabile,Exposure to welding particles in automotive plants, Journal of Aerosol Science 42, 2011,pg. 295-304.

5. AZIAN BINTI HARIRI, THE DEVELOPMENT OF WELDING FUMES HEALTH RISK ASSESSMENT TOOL FOR AUTOMOTIVE COMPONENT RELATED INDUSTRIES,Ph.D thesis , Universiti Tun Hussein Onn Malaysia,2015.

6. Jeffrey R. Walls, Characterization of Work Practices and Ventilation Techniques in Shipyard Confined Space Welding, M.S.C Thesis, University of Washington, 2012.

7. User's Guide for Extech Instruments, Model 451181 Data logging / Printing Anemometer+Psychrometer.(2010).

8. Versteeg H. K. , Malalasekera W. , An introduction to computational fluid dynamics-the finite volume method, Longman, 2nd Edition, 2007.

9. ANSYS, Inc. (2013), Users Guide, 15 version.

10. Iraqi standard for Ambient Air Quality from Directorate of the Environment of Basra,2016.

11. D.R Qugston, S.L Hodkinson, Faber \& Kells Heating and Air conditioning of Bulding, page 401-429, 2008.

12. AHMED ABDULELAH SALIM, Theoretical and experimental study of thermal comfort and contaminant removal in hospital operating room, M.Sc. thesis, UNIVERSITY OF BASRAH, 2012. 


\section{NOMENCLATURE:}

(CFD) Computational Fluid Dynamics.

(CFM) $\quad \mathrm{ft}^{3} / \mathrm{min}$

(CMM) $\mathrm{m}^{3} / \mathrm{min}$

(CRE) Containment Removal Effectiveness

(exp) experimental

(Nu) numerical.

(HVAC) Heating Ventilating Air Conditioning.

(TNu.) Numerical temperature
( $V_{\text {exp. }}$ ) experimental Velocity

( $\left.\mathrm{V}_{\mathrm{Nu} .}\right)$ Numerical Velocity

(р) Density. $\left(\mathrm{Kg} / \mathrm{m}^{3}\right)$

(IAQ) Indoor Air Quality.

$(S \varnothing)$ source rate per Unit volume.

(Texp.) experimental temperature. 